Portland State University

PDXScholar

$1-1-2011$

\title{
Jacob Burckhardt: History and the Greeks in the Modern Context
}

Anthony Rhodes

Portland State University

Follow this and additional works at: https://pdxscholar.library.pdx.edu/open_access_etds Let us know how access to this document benefits you.

\section{Recommended Citation}

Rhodes, Anthony, "Jacob Burckhardt: History and the Greeks in the Modern Context" (2011). Dissertations and Theses. Paper 279.

https://doi.org/10.15760/etd.279

This Thesis is brought to you for free and open access. It has been accepted for inclusion in Dissertations and Theses by an authorized administrator of PDXScholar. Please contact us if we can make this document more accessible: pdxscholar@pdx.edu. 


\title{
Jacob Burckhardt:
}

History and the Greeks in the Modern Context

by

Anthony Rhodes

A thesis submitted in partial fulfillment of the requirements for the degree of

\author{
Master of Arts \\ in \\ Interdisciplinary Studies
}

Thesis Committee:

Richard H. Beyler, Chair

Steven Fuller

R. Kevin Hill

LeeromMedovoi

Portland State University

(c) 2011 


\begin{abstract}
In the following study I reappraise the nineteenth century Swiss historian Jacob Burckhardt (1818-1897). Burckhardt is traditionally known for having served as the elder colleague and one-time muse of Friedrich Nietzsche at the University of Basel and so his ideas are often considered, by comparison, outmoded or inapposite to contemporary currents of thought. My research explodes this conception by abandoning the presumption that Burckhardt was in some sense "out of touch" with modernity. By following and significantly expanding upon the ideas of historians such as Allan Megill, Lionel Gossman, Hayden White, Joseph Mali, John Hinde and Richard Sigurdson, among others, I am able to portray Burckhardt as conversely inaugurating a historiography laden with elements of insightful social criticism. Such criticisms are in fact bolstered by virtue of their counter-modern characteristic. Burckhardt reveals in this way a perspicacity that both anticipates Nietzsche's own critique of modernity and in large part moves well beyond him.
\end{abstract}

Much of this analysis is devised through a genealogical approach to Burckhardt which places him squarely within a cohesive branch of post-Kantian thought that I have called heterodox post-Kantianism. My study revaluates Burckhardt through the alembic of a "discursive" post-Kantian turn which reinvests many of his outré ideas, including his radical appropriation of historical representation, his non-teleological historiography, his various pessimistic inclinations, and additionally, his nonempirical, "aesthetic" study of history, or "mythistory," with a newfound 
philosophical germaneness. While I survey the majority of Burckhardt's output in the course of my work, I invest a specific focus in his largely unappreciated Greek lectures (given in 1869 but only published in English in full at the end of the twentieth century). Burckhardt's "dark" portrayal of the Greeks serves to not only upset traditional conceptions of antiquity but also the manner in which selfconception is informed through historical inquiry. Burckhardt returns us then to an altogether repressed antiquity: to a hidden, yet internal "dream of a shadow."

My analysis culminates with an attempt to reassess the place of Burckhardt's ideas for modernity and to correspondingly reexamine Nietzsche. In particular, I highlight the disparity between Nietzsche's and Burckhardt's reception of the "problem of power," including the latter's reluctance - which was attended by ominous and highly prescient predictions of future large-scale wars and the steady "massification" of western society - to accept Nietzsche's acclamation of a final "will to power." Burckhardt teaches us the value of history as an active counterforce to dominant modern reality-formations and in doing so, his work rehabilitates the relevance of history for a world which, as Burckhardt once noted, suffers today from a superfluity of present-mindedness. 
Table of Contents

Abstract

i

Chapter I

Introduction

Chapter II

Contextualizing Burckhardt's Historiography

Chapter III

Elements of Heterodox Kantianism: Aesthetics and a New "Objectivity"

Chapter IV

The Greek Lectures

Chapter V

The Problem of Power: Burckhardt Contra Nietzsche

Notes

Works Cited 


\section{Introduction}

Nothing is more sacred than history. It is the great mirror of the world spirit.

- Franz Gerlach ${ }^{1}$

All human knowledge is accompanied by the history of the ancient world as music is by a base-chord heard again and again; the history, that is of all those peoples whose life has flowed together into our own.

- Jacob Burckhardt, The Greeks and Greek Civilization

Every great human being has a retroactive force: all history is again placed in the scales for his sake, and a thousand secrets of the past crawl out of their hideouts - into his sun. There is no way of telling what may yet become history some day. Perhaps the past is still essentially undiscovered! So many retroactive forces are still required!

- Friedrich Nietzsche, The Gay Science

...it is only to the extent that I am a pupil of earlier times, especially the Hellenic, that though a child of the present time I was able to acquire such untimely experiences. That much, however, I must concede to myself on account of my profession as a classicist: for I do not know what meaning classical studies could have for our time if they were not untimely - that is to say, acting counter to our time and thereby acting on our time and, let us hope, for the benefit of a time to come?

- Friedrich Nietzsche, On the Uses and Disadvantages of History for Life

The growth of the reputation of the Swiss historian Jacob Burckhardt in recent intellectual-historical appraisals is largely due to the rediscovery of the scathing and prophetic views of modernity propounded in his Reflections on History as well as his various allusive prefigurements of structuralist and postmodern theories. ${ }^{2}$ Much of Burckhardt scholarship attempts to situate his ideas in relation to those of the presumptive sine qua non of the modern shift, Friedrich Nietzsche - indeed, such a comparison is inescapable. Yet, in my view, prior attempts to unravel the "Nietzsche question" for Burckhardt have failed to consider in full the ethical-dynamic views of history shared by these two figures or the centrality of their iconoclastic, perspectivist historiographies - specifically in the case of their respective conceptions of the 
Greeks. Comparisons of Burckhardt and Nietzsche often pass over the broader philosophical continuities (and even some of the significant discontinuities) of their respective ideas.

Within this field of scholarship there exists a need to reconsider the relevance of Burckhardt - whom the twentieth century historian, Friedrich Meinecke, described as someone who saw "deeper and more sharply into the historical essence of his own time [than all others]" - as a trenchant critic of modern society. ${ }^{3}$ In order to better understand Burckhardt we must revisit his connection with Nietzsche and in so doing consider him as a precursor to Nietzsche instead of only an afterthought. It is my hope that by releasing Burckhardt from the daunting shadow cast by his most famous student, we may finally understand him as an autonomous thinker. ${ }^{4}$

There are three main reasons for the restrictiveness of Burckhardt scholarship to date. First, as Lionel Gossman has pointed out, Burckhardt's most ruminative and unconventional history, his Greeks and Greek Civilization, appeared in English in full only in the last decade of the twentieth century (some one hundred years after its first complete posthumous publication in German in 1898). Therefore, as Gossman notes, this major work has rarely been commented on or referred to - or perhaps read - even read by English-speaking scholars. ${ }^{5}$ A second issue is the widespread tendency in Burckhardt scholarship to view him, in light of Nietzsche, and in comparison to Ranke and to positivism, as something of an anti-modern, déclassé intellectual. ${ }^{6}$ In the third place, scholars often overlook both the direct and indirect influence of Kant in this context. Kant and the Kantian philosophical legacy at large did much, as R. Kevin Hill has reasoned, to shape the intellectual milieu that harvested much of 
Nietzsche's - and also Burckhardt's - formative ideas. ${ }^{7}$ Burckhardt and Nietzsche espoused common intellectual convictions which place them in a cohesive philosophical tradition that I will henceforth call heterodox post-Kantianism. An adequate understanding of this important philosophical kinship, including considerations of its broader genealogical significance, is critical to gaining a thorough understanding of both thinkers. In particular, by applying the subtext of post-Kantianism as our primary frame of inquiry, I hope to alleviate some of the relative obscurity and opaqueness of Burckhardt's and Nietzsche's ancient Greek receptions and to, in this way, reassess the present-day relevance of their respective critiques of modernity.

Conventional scholarly accounts of Burckhardt have tended to paint him as a classical German ideologue and as a conservative-reactionary thinker who, in spurning the ills of modern society, advocated a retreat into the cultural-historical chrysalis of ancient Greece and Renaissance Italy. ${ }^{8}$ This perception, however, undermines the complexity underlying Burckhardt's views about contemporary society; also it neglects his abiding appreciation for the role that the study of history plays as an active counterforce to modern power structures. Burckhardt condemned the democratization of culture in a way that ostensibly aligns him with a tradition of political-cultural conservatism as old as Plato. ${ }^{9}$ This disparagement of various "progressive" truisms does not, however, necessarily align him with identifiable antimodernists like Hobbes (who championed the total exploitation of power) or even Burke (who supposed that history is the direct materialization of God's will). On the contrary, as Richard Sigurdson has asserted, Burckhardt shares "many of the ideals of 
the so-called aristocratic liberals: thinkers such as Tocqueville and Mill, as well as Humboldt; in several dimensions, his analysis of freedom and individuality is liberal, and his prescriptions for a limited state are also classically liberal. ${ }^{, 10}$ Burckhardt's social-political perspective was imbued so thoroughly with a familiarity of the Greek polis, Italian commune and, above all, the Swiss canton, that any attempted political reading of his work that purports to situate his views in relation to the restricted modality of politics and the modern nation-state, e.g. German "conservativism," is fundamentally misguided. The peculiar sensitivities of Buckhardt's critical temperament arose in part as a result of a geographical-ideational aloofness that he shared with Nietzsche - an "otherness" which lends itself to the interrogation of various regimes of historical truth, culminating in the interrogation of interiority itself.

I will approach Burckhardt and his view of the Greeks by first revaluating his alleged ideological conservatism for the reason that this view commonly leads to the misapprehension of his greater agenda as an historian and furthermore undermines Burckhardt's crucial role in the inauguration of a new "counter-Enlightenment" historiography - to use Isaiah Berlin's term. ${ }^{11}$ Following this clarification, I will make an effort to sketch the lineaments of Burckhardt's theory of history, including the substance of his Kulturgeschichte as a rejection of traditional German historicism. Lastly, having laid the groundwork for the contextualization of Burckhardt's reception of Greek culture, I will then investigate his assessment of the Greeks in light of various divergences from conventional conceptions of antiquity, so as to situate Burckhardt's Greece in the historian's greater ideational "scaffolding" and 
thereby re-examine his place in the pantheon of modern intellectuals, particularly in comparison with Nietzsche. ${ }^{12}$

\section{A. Some Notes on Heterodox Kantianism}

Given that an understanding of heterodox Kantianism provides something of a foundation for the present study of Burckhardt, it is useful to clarify its defining characteristics and to additionally spell out Burckhardt's placement within this framework. In their own studies on Kantianism, Julian Young and Paul Guyer both conclude that while, in large part, Kantian reception in the nineteenth century tended to acknowledge the overarching positive view of the elements and limits of human knowledge presented in the Critique of Pure Reason, there existed too a contrary inclination to understand Kantian philosophy as fundamentally deflationary: ${ }^{13}$

Kant's refutation of Humean skepticism, that is, his proof and explanation of the existence of synthetic a priori cognitions by appeal to the very condition of the possibility of our own experience, seems to drive him into something like Cartesian skepticism, the denial that our way of representing things has any necessary resemblance to the way things are in themselves. ${ }^{14}$

In my view, Burckhardt and Nietzsche are, by way of the philosophy of Schopenhauer, exponents of this deflationary reading of Kant.

Kantianism in the nineteenth century was subject, in general, to three distinct characteristic interpretations. I will designate these categories as: positive Idealism, positivist Neo-Kantianism and heterodox Kantianism. In the first two cases the appropriation of Kant led toward a general affirmation of reason and its practicalconstructive application. Below I will refer to these cases together as the pro- 
Enlightenment or orthodox Enlightenment perspective. By positive Idealism, I mean the viewpoint, exemplified by Hegel and others, which takes Kant's claim that all knowledge is subject to the necessary limitations imposed by our mind-dependent experience of reality as an indication that absolute knowledge is attainable. This position is supported by the belief that reality is, ipso facto, a mental construct. Positive Idealism places a premium, albeit somewhat paradoxically, on the idea that the thing-in-itself is in some way decipherable as a manifestation of history at large, of moral progressivism and related phenomena. It is a perspective that champions the reflexive correspondence of human rationality and the world as such and is thus optimistically teleological. Positivist Neo-Kantianism similarly regarded the cognitive limitations intimated by Kant as fundamentally constructive. Given that Kant deems non-empirical objects as unknowable, positivist Neo-Kantians - e.g. Spencer, Comte and also Ranke - diminish (and sometimes completely eradicate) the place of the thing-in-itself, and in doing so they maintain a strict conceptual delineation between metaphysics and empirical knowledge, whereas Hegel and other pure idealists commonly avoid such a division. In this case moral action is possible and moral results are attainable, since morality is grounded in the purported soundness of reason.

Heterodox Kantianism defines an understanding of Kant that undercuts the pretensions of rationalism and questions the central notions that reality is both knowable and correctable by practical action. Heterodox Kantianism comprises: (1) a generally skeptical disposition. It regards Kantian philosophy as confirming the insuperable limits to human knowledge and the basic inadequacies of concept- 
mindedness. Seen in this light, the qualitas occulta of a particular object remains forever inaccessible to us through the channels of practical knowledge. Heterodox Kantianism is additionally marked by (2) an overt anti-teleological conviction that challenges the presumption that history encompasses a monotonic advancement of the absolute objectification of reason, ascertainable by human ken. Finally, I take this interpretation of Kant as (3) a rejection of the claim that morality is governable by reason alone. In this way, moral judgments descend from various socialpsychological forces. Human desires are, with respect to this post-metaphysical outlook, insatiable and ultimately futile, so any attempt to counteract human suffering by regulating our primal (and irrational) impulses by reason or by ascribing a transcendental purpose to a moral system, is therefore useless. Nietzsche's essay "On Truth and Lie in an Extra-moral Sense" is a good example of the first quality listed above, Schopenhauer's The World as Will and Representation (particularly Book II) and Nietzsche's Birth of Tragedy exemplify the second type, and Nietzsche's The Genealogy of Morality is a model of the third type.

Schopenhauer serves a central role in the schematic of heterodox Kantianism. He is the prototypical figure for whom the philosophy of Kant serves a primary deflationary function. In his reading of Kant, Schopenhauer denies our ability to access the thing-in-itself through ordinary representation (Vorstellung) and holds that a genuine aesthetic state offers the best hope to counteract the futility of practical activity. Schopenhauer maintains that practical knowledge fails to generate any form of positive understanding about the noumenal world. His general position is that of skeptical epistemology despite his claims to the "metaphysical deciphering" - via the 
will - of the world, as he notes:

[my metaphysics is] like an arithmetical sum that comes out, although by no means in the sense that it leaves no problem still to be solved, no possible question unanswered. To assert anything of the kind would be a presumptuous denial of the limits of human knowledge in general. Whatever torch we kindle, and whatever space it may illuminate, our horizon will always remain encircled by the depth of night. ${ }^{15}$

I agree with Young's assertion that in his final analysis, Schopenhauer makes no claim about how reality actually is in itself. ${ }^{16}$ Schopenhauer equates the will with Kant's thing-in-itself: "it is precisely my great discovery that Kant's thing-in-itself is that which we find in self-consciousness as the will." He nonetheless conclusively retracts any acknowledgement that his discovery of the will directs one to data that transcends the confines of appearance, noting instead: "this will is thing in itself merely in relation to appearance... what, however, the thing in itself is outside that relation I have never said, because I don 't know it." He concludes, "in that relation it is [an unqualified] will to life." ${ }^{17}$ Young perceives in the late Schopenhauer a "reconciliation" of lingering philosophical inconsistencies that otherwise threaten the plausibility of Schopenhauer's system as a whole. Schopenhauer admits plainly that his philosophy is concerned with "immanence." The world is will - we experience it as will in a syntactically free way, in the absence of language and of any manner of cognitive objectification owing to the immanence of our being (in the world). We cannot "know" the will since we only comprehend it by way of the crude approximations that attend cognition - through, that is, the filter of representation: "[to ask whether the will can be known] in general...can never be answered, because... being-known of itself contradicts being in itself, and everything that is 
known is as such only appearance." Young emphasizes the strong deflationary aspect of Schopenhauer: "[he] realizes that not only can he allow his philosophy to end on a 'negative' note...but that it actually demands that it should." 18

Schopenhauer, Burckhardt and Nietzsche all imagine the principal task of philosophy (or history qua philosophy) as bound up in an effort to ameliorate the asperity of life. They all fix on the tension between viewing the human condition as a source of misfortune and grief or as a source of potential exultation. In this way, Burckhardt - and Nietzsche will follow him here - imagines himself as expressing a particular Greek sensibility. These existential frictions are best captured in the case of the significant change of temperament that accompanies the transition from the rather morose end of Book II of Schopenhauer's The World as Will and Representation to that of the more "hopeful" content of Book IV. Young identifies this key transition as a turn to an aesthetic "consolation," toward, to borrow a phrase employed by the young Schopenhauer, a "better consciousness."

Aestheticism, as will become clearer in what follows, provides Schopenhauer (and also Burckhardt and Nietzsche), with an avenue for validating his "negative" appropriation of Kant on the grounds that it circumvents many of the problematic contingencies that accompany the pure Idealist and positivist variations of Kantianism. The framework of aesthetics offers a counter-objective account of the world and thrusts the subject into a heightened condition of reflexivity. Heidegger has said, to this end: "[our] task is to see the riddle [but not to solve it]"; aesthetics allow us to see but never to know. By Schopenhauer's lights, aesthetic consciousness prompts us to abandon: our basic egocentricity, our concerns over a sense of 
subjective happiness and our longing to seek out merely "practical" ends.

We forget our individuality, our will, and continue to exist only as pure subject...so that it is as though the object alone existed without anyone to perceive it, and thus we are no longer able to separate the perceiver from the perception, but the two have become one since the entire consciousness is filled and occupied by a single image of perception. ${ }^{19}$

The recognition of the limits of human knowledge necessitates an effort to modulate our conception of representation, i.e. our relationship to objects of knowledge.

Schopenhauer directs the subject of the aesthetic experience to undergo an internal transformation so as to become "pure will-less, painless [and] timeless subjects of knowledge“ - to act, in other words, as if one were free from the snare of mortal contingency - to live fictively, like a God.

\section{B. Burckhardt and Nietzsche in Basel}

Burckhardt and Nietzsche shared intellectual affinities that separated their ideas from various modes of orthodoxy. Their common historiographical perspective is underscored by the kinship of their unconventional Greek studies. Comparisons of Burckhardt and Nietzsche often minimize the influence that Burckhardt exerted on Nietzsche. ${ }^{20}$ In his letters, Nietzsche openly acknowledged his debt to Burckhardt and recognized the close proximity of their ideas; however, Burckhardt shied away from such direct comparisons, perhaps sensing that Nietzsche might one day emerge as "a sort of power...[a name] which asks for nothing more than discussions pro and contra." 21

Nietzsche became full professor at Basel, along with Burckhardt, at an unusually young age in 1869. He considered Burckhardt to be a kindred spirit and 
something of a mentor from the very beginning of their acquaintance. Though Nietzsche later broke with onetime mentors such as Schopenhauer and Wagner, he never seems to have lost any sense of the intense reverence he held for Burckhardt: "Now you are - thou art - our greatest teacher," he wrote to Burckhardt in an 1889 letter, one of the last before his final mental collapse. As early as May of his first year in Basel, Nietzsche relates that he had lunch every day at a restaurant near the central railway station with three other colleagues and that his closest associate was Burckhardt, "the famous teacher of aesthetics and art history and a very smart man." Nietzsche wrote, in a letter from 1870, only eight weeks after his arrival in Basel: "From the start I got into close touch with the intellectual oddity Jacob Burckhardt and I am delighted about it...[together] we have discovered that our aesthetic paradoxes are wonderfully congruent.” Nietzsche's correspondence additionally reveals that in his first year at Basel he and Burckhardt often walked three miles or so to a neighboring town discussing Schopenhauer, referring to him as "the philosopher." Nietzsche also attended many of Burckhardt's lectures in person, including his Greek Lectures (1869) and lectures On History (1870). In a late work, Twilight of the Idols (1888), Nietzsche reveals his debt to Burckhardt's Greeks explicitly: "Whoever has investigated the Greeks, such as the profoundest student of their culture now living, Jacob Burckhardt of Basel, realizes at once the value of this approach [namely, recognition of the Apollonian-Dionysian distinction]." On the subject of Burckhardt's lectures on the study of history, Nietzsche recalls that they were tinged with "the spirit of Schopenhauer." 22 He sensed through these lectures that Burckhardt's seeming, "classically serene façade" was merely a mask that covered a 
disquieted soul - a Dionysian spirit - much like his own. ${ }^{23}$ Following the Greek lectures, Nietzsche described Burckhardt in 1870 as "that elderly highly original man, given, not to distorting truth but to passing it over in silence," noting that his talks were marked by "profound thoughts [with their] strangely abrupt breaks and twists as soon as they touch the danger point." Nietzsche imagined himself as continuing, in some sense, a Burckhardtian program of critical historiography that dared to pursue such danger points.

Nietzsche regarded Burckhardt's counter-modern ideas as congruent with his own and Burckhardt openly conceded this opinion to some extent. This consonance is well captured in a correspondence the two shared at the time of Nietzsche's publication of Beyond Good and Evil (1886). As with all of his previously published texts, Nietzsche sent a personal copy to Burckhardt which included a note that is at once adulatory and heartfelt. In the 1886 letter he states:

I know nobody who shares with me as many prepossessions as you yourself; it seems to me that you have had the same problems in view - that you are working on the same problems in a similar way, perhaps even more forcefully and deeply than I...The mysterious conditions of any growth in culture, that extremely dubious relation between what is called the 'improvement' of man (or even 'humanization') and the enlargement of the human type, above all, the contradiction between every moral concept and every scientific concept of life...here is a problem we fortunately share with not very many persons living or dead...My comfort is that, for the time, there are no ears for my new discoveries - excepting yours, dear and deeply respected man; and for you again the discoveries will be nothing new! ${ }^{24}$

Burckhardt's reply, the last letter he would send to Nietzsche, while at times chilly and expressly diplomatic, as was his wont with most of Nietzsche's overtures, nonetheless conveys a sense that Burckhardt agreed with certain of the similarities 
that Nietzsche had drawn between the two. Burckhardt lists specific points of continuity and general interest in Nietzsche's text: “on the will of nations, and its periodic paralysis; on the antitheses between the great security given by prosperity and the need for education through danger; on hard work as the destroyer of religious instincts; on the herd man of the present day and his claims; on democracy as the heir of Christianity; and quite specially on the powerful on earth of the future!" While Burckhardt, on this last note, understood a definite parallel between his own awareness that Europe needed something of a future "noble-type" as a way to access her lost cultural heritage with Nietzsche's related ideas, he later, after Nietzsche's eventual mental deterioration, censured the latter's affinity for the Gewaltmenschen, or power-maniacs, over rulers who exhibit a genuine nobility of culture. ${ }^{25}$ 


\section{Contextualizing Burckhardt's Historiography}

\section{A. "Unseasonable" Basel: A Counter-Modern Dialectic}

Lionel Gossman has observed, that with few exceptions, scholarly literature has understated the influence of the peculiarities of the "unseasonable" climate of Basel and to some extent, Switzerland more broadly, on the thought of both Burckhardt and Nietzsche. ${ }^{1}$ To be sure, Switzerland owns an extensive heritage of independence and willed isolation from much of the political upheavals of greater Europe dating back to the early modern period. It has accordingly, as H.R. TrevorRoper has noted, "always been the refuge and sometimes the cradle of intellectual heresy." Switzerland has harbored at various times thinkers as diverse and "heretical" as Calvin, Erasmus, Rousseau, Lenin and Einstein. "Foreign ideas, flowing in from France, Germany and Italy, but cleansed from coarse taint of nationality, have often

received there new character and new vitality." In fact, Jacob Burckhardt celebrated his so-called "Archimedean point outside events" in Basel for the reason that it placed the mare nostrum of Renaissance and antique culture to his south as well as the seat of German culture to the north, a source of certain dread for its potentially modernizing influence, equally within the historian's purview.

Basel provided Burckhardt and Nietzsche with several distinct perspectives that exerted a residual influence on their respective views of the Greeks as well as each of their larger intellectual aims. In the first sense, Basel to Burckhardt and Nietzsche was a modern city-state similar to both the Italian commune of the Renaissance and the Ancient Greek polis. Basel represented an antithesis to the 
metropolitan tendencies of nineteenth-century Europe and this perspective, while not exclusive to Basel, was felt in a profound way by Burckhardt and Nietzsche. Together, the refusal of the citizens of Basel to have the city's medieval wall demolished in order to accommodate commonplace modern urban modifications, the widespread dismay in Basel at the 1874 revision of its constitution which officially relinquished its six-century-long cantonal autonomy to a newly-formed Swiss central government, and the affected pride of its citizenry for their world-famous ribbon manufacturing industry all point to something of the recherché aspect of Basel to which Burckhardt and Nietzsche each paid deference in their various public addresses. ${ }^{3}$ Nietzsche would, just before his mental collapse, proclaim to Burckhardt, possibly only in partial jest, that "I would much rather be a Basel professor than God." ${ }^{4}$ The historian Emil Dürr, as Gossman notes, explained the peculiar connection between Burckhardt and Basel thus:

In the year 1833, in consequence of a revolution, Basel experienced the great political misfortune, as is often, said, of separation from its surrounding countryside. But if one considers the higher, cultural fate of the city, this separation was its true good fortune. For it was only because of that separation that Basel and its urbane culture were spared from falling under the influence of the country districts, the peasants, and the populations of the small country towns; it was only because of that separation that it was saved from the cultural and moral centralization that was the fate of all other Swiss cities and urban cultures - with the exception of Basel and Geneva. Basel did not have to go through the process of complete democratization and rationalization until 1875 ...but in the meantime, it had consolidated, expanded and saved its urban culture. That urban and urbane culture always remained the climate that best suited Burckhardt. And so it came about that this city-state, created forcibly out of revolution, allowed Burckhardt to live as what he truly was: a cosmopolitan in that high spiritual sense and in that ideal world imagined and lived by a Schiller or a Goethe, or by the ancient Greeks themselves. ${ }^{5}$ 
Basel exemplified something of a last bastion of "old Europe," to use Burckhardt's well-worn term. Its civic leaders, which included members of Burckhardt's family, still claimed to uphold their historic noblesse oblige which belied the new "bourgeois spirit" of the times. Burckhardt regarded such tokens of historical continuity as an antidote to the selfish autonomy and cultural myopia of modern mass society. As Richard Sigurdson has put it:

An inescapable element of Burckhardt's political thought is its vehement antipathy to the spirit of democracy and to the demand for greater equality...Burckhardt mocked the call for universal suffrage and saw in the right of greater political participation by all classes a pathetic tendency towards 'leveling down' and greedy mediocrity ${ }^{6}$

In an article on Wilhelm Vischer, Burckhardt's historian-protégé and long-time friend at the University of Basel, Gossman discusses the reception of "culture" within the Basel Gemeinschaft or community:

Culture, in short, was a property of the community or - one might wish to specify - of the ruling class in the community. It was what entitled that class to play the leading role it played, and it prepared it to play its role wisely and with humanity. It was a patrimony to be carefully husbanded, handed down, and protected from the acquisitive designs of outsiders who, from the point of view of the 'legitimate' owners, could only exploit it and, in the end, dissipate it. ${ }^{7}$

Burckhardt professed, in a way that may seem alien and paradoxical to many modern readers due to its explicit anti-egalitarian implications, that Basel best resembled the atmosphere of the Greek polis, "where the largest proportion of the members of the state are citizens in the fullest sense of the word." In a like manner, Nietzsche, J.J. Bachofen, and Franz Overbeck all expressed a similarly placed affection for the city and a certain consonance of related cultural-political convictions. For Burckhardt in particular, and Nietzsche subsequently, Basel typified an ideal balance between 
individual and state; it cultivated an atmosphere that brought together the "subjective and objective individual into a meaningful whole" and accordingly provided a tonic against the atomization and alienation of the individual in modern society. ${ }^{8}$

Basel's traditional appropriation of the Gymnasium education model, particularly in the case of its commitment to classical studies, typifies something of the city's cultural dynamic. In the first place, the influence of the Prussian minister of education Wilhelm von Humboldt's education reforms was felt in Basel in the form of the model of "inwardness." Humboldt encouraged the notion of education as selfedification. This idea gained traction in Basel in part because it seemed to harmonize with the city's celebrated "anachronistic" spirit. Basel education encapsulated together the cosmopolitan and parochial - a sense of the new and old - dichotomy of the city. Humboldt's reforms were congruent with the appropriation of Greece encouraged by German neohumanism which purposely set itself apart from the utilitarianism and modern "refinement" of the English and French Enlightenment traditions. The high esteem Humboldt granted the individual reassessment of primary classical texts through close - even "spiritual" - readings was of incalculable importance, as we shall see, for both Burckhardt and Nietzsche. Gossman elaborates:

[For] Humboldt the study of antiquity is not a grammatical and rhetorical exercise; it is not a study of finished products or literary works but an attempt to enter into and reappropriate the creative spirit that engendered them; ... If anything, then, far from the study of ancient languages being an approach to the study of texts, the study of ancient texts was a way of getting to the creative 'spirit' of the language and culture that produced them. ${ }^{9}$

Humboldt advanced the model of Bildung (individual self-cultivation). Besides absorbing the classical leanings and the newfound stress on inwardness of Humboldt- 
era German education, Basel schools did not succumb in full to the mounting pressure to mold their curricula to accommodate the ever increasing demands of the age for the very reason that such concerns were disapprovingly linked to the philistinism of French and German bourgeois culture. The Basel system sought to maintain the high spiritual ideals of neohumanism in light of the new challenges posed by the prevalence of scientific and technical education. While the Basel Gymnasium system did provide certain concessions to the real-world demands of modernity at large, as in the case of the coeval rise of the Realschule, Basel concurrently retained a countermodern core of humanities and classics curricula at both the university and the Pädagogium - a broadly-focused preparatory school for future non-academic professionals exclusive to Basel. In contrast to the nine-year classical Gymnasium that was standard in Germany, a six-year Gymnasium offering both a classical and a modern track...together with the Pädagogium was designed to offer an appropriate general and classical education to a distinguished class of pupils who did not plan to go on to professional studies at the university. ${ }^{10}$ Bildung came then to acquire a particular réclame in Basel. For Burckhardt, in particular, Bildung represented an allegorized triumph of culture over politics; a fortiori: the triumph of Basel over Prussia.

Much of the substantive content of Burckhardt's biography indicates that a great many of his enduring reservations about the direction of modern society were rooted in the specific socio-political experience of nineteenth century Basel vis-à-vis Germany. Accordingly, Burckhardt's ideological perspective was devoid of the nationalistic, racial, realpolitische and destiny-laden pitch that defined much of what 
is, by present-day standards, considered "anti-progressive" thought from this time. It is useful in this regard to contrast Burckhardt's ideas with those of a contemporary arch-conservative thinker like Lagarde or Mommsen. ${ }^{11}$ Burckhardt's cultivation amidst the ancien régime of Basel and atmosphere of traditional Gemeinschaft appropriately inspired his rejection of many orthodox Enlightenment views. His chief "political" concern for modernity was for the threat to human freedom and potential self-fulfillment included with the promise of infallible "progress" and the hegemony of democracy. Burckhardt's historical works repeatedly reveal misgivings about the so-called progressive developments of western society: the rise of nation-states, the hypertrophy of centralized political power, the revolutionary potential of the masses, the predominance of industrialization and materialism and the commodification of art and culture in the hands of the bourgeoisie. In opposition to the dominant modernist liberal-populist model, Burckhardt praised the virtues of Kleinstadt as a means to facilitate trans-national sympathies, as well as a manner of education as the notion of Bildung that accorded with the culture of authentic individualism.

Certainly the "dialectic of Basel," as John Hinde has at various times referred to it, bore something of the aesthetic, elegiac, and ethical (as opposed to "moralizing") qualities of German neohumanist philhellenism at large. But for Burckhardt and similarly Nietzsche, the Kulturgeschichte of the broadly "German" type, viz., that of Winckelmann, Humboldt and especially Hegel, assumed to varying degrees the basic suppositions of the principles of 1789. Burckhardt came to view German philhellenism as host to the parasitic myth of the triumph of human reason and the false rectitude of the optimistic will. The Greeks too, it seemed, were now 
confined, to draw from Weber, in the "iron cage of reason" owing to the modern hypostatization of "objective consciousness."12 Burckhardt recognized in his Reflections on History that the forces of the French Revolution were "still active and will continue to be so with that world age whose further development we do not know as yet," thus concluding: "Above all, the revolution has had results which now completely shape us and constitute an integral part of our...conscience - things, therefore, that we can no longer separate from ourselves." Accordingly the spirit of the revolution, i.e. the predominant spirit of modernity, had not only altered the course of the present but it had also altered the past. The formerly "lost time" of antiquity, once shrouded in the mists of uncertainty, had been "found" anew and exposed to the light - and persistence - of reason; modernity gazed at once into the "great mirror" (Gerlach, Ch.1). ${ }^{1}$

Burckhardt's reading of the French Revolution as an irreversible culturalhistorical shift marked the beginning of his definitive break from mainstream postEnlightenment thought. ${ }^{13}$ The French Revolution reinforced Burckhardt's conception of the anti-rational and non-teleological nature of history, the ascendancy of the place of myth for modern historiography, as well as his historical pessimism. It is illustrative to compare the role that a "great man" like Napoleon played in the diagrammatic framework of the objective historicism of Hegel, to the contrary role he played in Burckhardt's historiography. ${ }^{14}$ For Hegel, Bonaparte serves as a vessel for an unremitting world-spirit; he is nonetheless, in Hegel's words, a mere "historical actor" who, though purblind to the grand desideratum of history - the authentic actualization of freedom as such - plays a central role in its irrepressible finale. Hegel 
sees history as structurally narrative: it has a clear beginning, middle and end. Additionally, Hegel regards the historian's narrative as objectively valid given that the world is a priori governed by reason. Hegelian objective historicism likewise reaffirms present-day modes of power (reason being the foremost) - it sees the present as disclosing an immutable and cognizable historical meta-process:

"Napoleon [is] the Zeitgeist on horseback," Hegel declares. ${ }^{15}$

Burckhardt's contrasting view of Napoleon shows the wide gulf that separates his historiographical project from Hegel's objective historicism. For Burckhardt, Napoleon is not the emissary of a providentially authorized design; instead, he is a token of historical caprice - of Eris, even. Bonaparte was not granted his "greatness" by the benevolent and reasonable hands of the demiurge or some such entity but was instead a vessel for purposeless, unmitigated power. Napoleon, like Borgia for Nietzsche, epitomizes the defiant pluripotency of the individual; he is the heroic overman. ${ }^{16}$ Napoleon signifies the unreflective or ahistorical element of man. He is accordingly absent the unity of synthesis which Anschauung (as aesthetic play) provides, since his is a metaphysics of power incongruent with the transcendent potential of culture.

And just as there are no "golden" ages of history in the minds of Burckhardt and Nietzsche - and hence no original Eden and no Fall in particular, so too there can be no faultless historical idols; even Greece, for that matter, was not without its dark, hidden recesses - its "tigerish" lusts. ${ }^{17}$

\section{B. "Alienated" German Philhellenism}

The "unseasonable" mood of Basel was exceptionally well-suited to the 
peculiar significance that the heritage of Greece held for nineteenth century German society - something Suzanne Marchand has described as a "cultural obsession.",18 Marchand's introductory comments on the cultural-revolutionary impulses, the antiBismarckian and likewise anti-Roman defiance of the majority "statist culture" of liberal modern Europe characteristic of German neohumanism are directly applicable to the atmosphere of Basel and the greater Burckhardtian historical project approached from the axis of Greek reception.

Greece...the powerless and almost extinct nation whose dignity and influence depended solely on its cultural legacy, appealed to the German Bildungsbürger, the young man seeking to rise by means of sheer intellect and hard work. Unquestionably, it was men of this ilk who...endowed German philhellenism with its characteristic aesthetic tenets and sociopedgogical form. Theirs was a generational revolt...but it was especially a cultural revolt, launched by intellectuals whose primary interests lay in the free cultivation of the arts and sciences and the universalization of non-utilitarian, aristocratic education. Greece appealed to this group not because democracy was born there, or because the Athenians possessed unique freedoms though these aspects lent Athens charm in some eyes - but because the ancient Greeks had achieved the pinnacle of artistic beauty; The foremost 'political' aim of the first Graecophiles was the reconfiguration of German cultural institutions, not the overthrow of the state. ${ }^{19}$

As Richard Sigurdson has reasoned, the social-political content of Burckhardt's historiography places him squarely in a group of contemporary intellectual outsiders who advocated a historically-activated "revolution" from within. In so many ways, Greece - by manner of its alleged hieros gamos (sacred marriage) with German society - remained for these theorists a catalyst for cultural regeneration, for the refurbishment of the spirit and the Innerlichkeit of the subject. ${ }^{20}$

Greek reception held a special significance in the German-speaking world in 
the nineteenth century, particularly in the case of various attempts to refashion and reinvent German culture at large. To be sure, Germany's delayed nationhood generated, as earlier J. G. Herder and others suggested, a pressing need to establish a definite heritage of historical-cultural antecedents which would serve to effectively authenticate "Germanness." It would seem the aura of Greece commands a certain, incomparable sense of veneration. Greece, to paraphrase Heidegger, is an inception it is the beginning of a beginning - an almost inconceivable "originary" moment which at once marks the genesis of History and signals too its inevitable demolition. ${ }^{21}$

M. S. Silk and J. P. Stern's classic text, Nietzsche on Tragedy, identifies German Hellenism - particularly through its heterodox culmination with Nietzsche (and also Burckhardt) - as typifying a current of modern criticism borne out of a "radically alienated situation." German cultural-criticism in the guise of Hellenism proceeds from a position of deep, tragic estrangement; it is steeped in a sense of willed, Odyssean exile: "[when] one is no longer at home anywhere, so in the end one longs to be back where one can somehow be at home because it is the only place where one would wish to be at home," and equally in a rooted conviction of the historically "fated" situation of German identity. ${ }^{22}$ Dennis Schmidt likewise recognizes the various tensions of German thinkers who contended with the wholesale "saturation of Western culture" by turning, in part, to what they perceived as the measureless profundity and richness of the Greek experience. ${ }^{23}$

The Kantian turn in philosophy did much to problematize, and likewise, to displace, the central precepts pertaining to metaphysics, epistemology, ontology and even politics in the Western tradition. It is right then to portray, as Schmidt, Silk and 
Stern do, the canonical "age of history" as a point of universal crisis - a crisis which at once envelops the question of the end of philosophy and even the end of history itself. ${ }^{24}$ With Kant, the question of human limits becomes ingrained in the experience of the human condition; self-understanding coordinates these very limits. ${ }^{25}$ In light of such "situatedness," German Hellenism embodied an effort to ascertain the "primal scene of Western identity" - to recognize the inescapability of our shared ontological finitude through the appropriation of an Ur-consciousness or Greek consciousness. The rediscovery of such "lost" historical experiences presents a new set of conceptual possibilities for both historical imagination and modern self-conception. This acute experience of what is sometimes referred to as historical "alterity" - specifically through the discordant confrontation of the historical Other qua the Greeks - defines the way in which Burckhardt and Nietzsche focus their respective attempts to situate, and by turns rectify, the crisis of modernity.

In one sense, Burckhardt works within the above-noted "alienated" branch of "German" philhellenism (that is to say, within a classical tradition of Greek reception adhereing to the "sacred marriage" posture). Yet, well before Nietzsche, Burckhardt began to divagate from many of the commitments of normative classicism.

J. J. Winckelmann effectively founded modern German philhellenism with his momentous hypothesis that classical culture is dominated by an ideal of beauty that exalts perfect, static harmony. ${ }^{26}$ This construct envisions the Greeks as figments of “noble simplicity and quiet grandeur." Read through a Burckhardtian lens, Winckelmann does not present the Greeks as a formidable historical Other, but rather as mere Ego-phantoms, that is, as projections of the modern pursuit of identity. 
Following in this same critical register, Lessing expurgates the Laocoön figure of its emotive and Dionysiac infelicities; Schiller accordingly writes of the broadly halcyon cheerfulness of the Greeks: "Not to that culture gay, Stern self-denial, or sharp penance wan! Well might each heart be happy in that day- For gods, the happy ones, were kin to man!"; and similarly, Goethe, perhaps the greatest single exponent of German cultural-philhellenism, exhorts us, simply, to "be Greeks" - that is, to be beautiful like the Greeks. ${ }^{27}$ It was only with Hölderlin in the last decade of the eighteenth century that Greek reception in Germany became both polyphonic and more introspectively vigilant. In his novel Hyperion, Hölderlin simultaneously attacks the alleged "imbalances" of German culture: "the overvaluation of philosophizing and the promise of action that never comes, the substitution of books and words for deeds, the lack of worldly competence." In addition, he repudiates Winckelmann's "homogeneous Greeks" by summoning a vision of the ostensible harmony of the Greeks as the product of darker, even proto-agonal forces. ${ }^{28}$

These initial challenges to classical German philhellenism were both exploited and broadened by Burckhardt. With Burckhardt, the question of "the importance of Greece" for Germany undergoes a significant transformation. Burckhardt's revaluation of Greece and its correlative implications for a larger critique of modernity can be effectively regarded as modulating the familiar "mirror" functionmodel of history. Here history serves a supra-mimetic purpose. For Burckhardt, history operates as a transfiguring mirror. In a similar way (in the "mnemohistory" of Freud studies), 'the past is not simply 'received' by the present. The present is 'haunted' by the past and the past is modeled, invented, reinvented and reconstructed 
by the present." ${ }^{, 29}$ Burckhardt returns us then not to some remote yet extant antiquity but instead to an altogether repressed antiquity: to a hidden, yet internal "dream of a shadow." ${ }^{30}$ His Greek project, like Nietzsche's subsequent project, consequently bears a double-Oedipal implication insofar as it is effectively patricidal - here the Laius figure is a composite of various German Enlightenment "fathers" - and replete with a variety of challenging repercussions pertaining to self-discovery. Lacan, in a related way, later lamented the modern loss of the "sense of tragedy" - of our estrangement from those of our ancestors who effectuated the unmasking of consciousness ab initio. ${ }^{31}$ Burckhardt's redeployment of the Greeks represents an effort to recover a pre-modern sense of being. In this way, he regards Greece as a site of dynamic historical inception:

An inception is not repeated when one shrinks back to it as something that once was, something that by now is familiar and is simply to be imitated, but rather when the inception is begun again more originally, and with all the strangeness, darkness, insecurity that a genuine inception brings with it. ${ }^{32}$

\section{Breaking Ranks: Formulating a Counter-Enlightenment Historiography}

Just as Burckhardt and Nietzsche opposed conventional Enlightenment historiography, their appraisals of Romantic historiography and Romanticism in general were unfavorable. Their unsentimental observations inspired in part by the ruminations of Schopenhauer on the subject of power, which blindly and inexorably directs history, plainly excludes them from such allegiances. ${ }^{33}$ The optimistic will of Romanticism is simply incompatible with the underlying entropic drift of the ideas of Schopenhauer, Burckhardt and Nietzsche.

A common acceptance of the premises of the Schopenhauerian world-as-will 
model underpins heterodox Kantianism. Its adherents harbored a sense of lingering epistemic doubt and were hence drawn to various anti-rational and related constructs. ${ }^{34}$ Burckhardt and Nietzsche were especially attuned, in a way that remarkably parallels concurrent fin-de-siècle developments in the sciences, to genuine deviations from the consensus reality of objective history. ${ }^{35}$ Although both championed a form of individual self-fulfillment generally, or even selftranscendence of some form, their shared problematical conception of man rendered the Romantic, basically triumphant vision of man falsely utopian. ${ }^{36}$

The Rousseauian-Romantic ideal of a pre-historical society rooted in a form of pure justice befitting the "noble savage," was of a piece, in Burckhardt's view, with a much broader modern crisis. The nineteenth century, the self-styled "age of history" was, paradoxically, an age which suffered from a superabundance of presentmindedness. History had degenerated by this time into an exercise in narcissism and derivative wish-fulfillments. The noble savage and the noble Greek were essentially tributes to the noble modern; "pure justice" and "quiet grandeur" were simulacra of Enlightenment virtues; as Habermas says, the primary desideratum of modernity is the "creation of a normativity out of itself." $" 37$ The presumptive assurance in a rational-self had alienated modern man from the "wounding" burden of consciousness qua historical understanding. ${ }^{38}$ Schopenhauer, Burckhardt would recall, claimed that "awareness of history is what restores unity to the consciousness of people." In losing sight of a genuine past, man had embarked upon a "new consciousness of existence...in [only] the present." According to Burckhardt, modern society had unmoored itself from the past and in so doing it had set itself adrift in the vast and 
perilous sea of the "blind will to change." Burckhardt offered the following

seemingly Schopenhauer-inspired comment about the new ahistorical age in his "The Age of Revolution" lecture:

Our task, in lieu of all wishing, is to free ourselves as much as possible from foolish joys and fears and to apply ourselves above all to the understanding of historical development. To be sure ...the age of revolution makes this objective understanding the most difficult for us. As soon as we become aware of our position, we find ourselves on a more or less defective ship which is drifting along on one wave among millions. But one could also say that we ourselves are, in part, this wave. $^{39}$

The historiographical aspect of Burckhardt's critique of modernity, buttressed by both his anti-historicist and anti-Romantic propensities as well as his distinctive interpretation of the legacy of the French Revolution, climaxes in his evocation of the so-called spirit of "eternal revision." This latter concept, propounded first in 1871, the year in which Bismarck completed the "iron and blood" unification campaign (an event Burckhardt seems to have regarded as a quintessential evocation of the spirit of eternal revision), encapsulates the modern appetite for perpetual change. Burckhardt argues:

The decisive new thing that has come into the world through the French Revolution is the permission and the will to change things, with public welfare as the goal. This new thing manifests itself in the equality which here places the decision for change in the hands of universal, or at least very extensive, suffrage. From this there results a change in all forms as soon as a new content makes itself felt. ${ }^{40}$

Burckhardt's negative appraisal of modernity is clear. Post-revolutionary ideology is saturated with a fetishization of change, of history-less revision. Enlightenmenthistoricist and Romantic preconceptions fortified the modern ethic of change for the sake of change in Burckhardt's view. Enlightenment ideology predisposed the 
apprehension of history to traditional narrative conventions, to the tableau of monotonic "progress." Romantic commitments equally propagated the illusory promise of the inherent "goodness" of man and, as we shall see, placed a premium on human "happiness."

Burckhardt's "eternal revision" is intimately connected to our present topic. It reveals in particular Burckhardt's deep-seated "ethical" concerns and his enduring sensitivity for "duty." The German Pietist tradition as well as the prevalence of Kantian ethics in the German-speaking world in the nineteenth century had much to do with shaping this particular outlook. ${ }^{41}$ And yet, due to the dual influence of Schopenahauer and the "dialectic of Basel," duty held also a slightly morose or pessimistic connotation for Burckhardt. He speaks of "the duty, incumbent upon us...to educate ourselves to be comprehending human beings" so that "every people is incomplete and [therefore] strives for completion." ${ }^{42}$ Burckhardt's sense of duty dovetails with the Kantian notion of self-willed Enlightenment. ${ }^{43}$

Burckhardt, however, additionally emphasizes the virtues of historical consciousness and the dangers of an ahistorical posture. According to this concept of duty, one's actions must be sustained by the proper comprehension of the conditions of possibility envisioned through historical knowledge. While the prevailing currents of modern, liberal ideology offered guarantees of the apodictic virtue of universal suffrage and of the divinely-sanctioned sovereignty of "the people" as a consequence of a will to eternal revision, such "improvements" conversely engender the increasing regulation and regimentation of individual behavior in addition to the widespread imposition of assorted circumferential normativities. As Gossman has observed, 
Burckhardt and Nietzsche were both convinced that "freedom has as much to fear from universal suffrage as from the ambitions of tyrants"; in fact, "they believed that [universal suffrage and the regeneration of tyranny] would play into each others hands." 44 This key revelation of the primary insidiousness of the "will to reason" led Burckhardt to anticipate the rise of both socialism and fascism and the synchronous mass upheavals of modern Europe. As early as 1846, he warned of a "social last judgment" and of the "general barbarism" of the coming "social revolution." In his later Reflections on History, Burckhardt echoed these concerns, warning that " The social' would assign to the state never-heard-of and outrageous tasks, which could be accomplished only by a mass of power which also was never-heard-of and outrageous" (Judgments on History, Chapter 5); said accumulations of power, Burckhardt expressly cautioned, will result in the unprecedented mobilization of massive standing armies and the potential conflagration of western society.

The seeming proximity of Burckhardt's "eternal revision" to that of Nietzsche's familiar doctrine of "eternal recurrence" warrants consideration. ${ }^{45}$ The relationship of these two ideas is based, in part, on their shared ethical content. For Burckhardt, the choice to follow one's duty concerning the attainment of historical understanding is a fundamental moral act, because "the historical" channels a particular aesthetic-metaphysical state. In this case, the failings of "eternal revision" reveal the cataclysmic potential of ahistoricality by ushering in the demolition of culture. $^{46}$

In the Nietzschean framework, the "eternal recurrence" plays an analogous role. The ethical content here relates to the interrogative construction of the "greatest 
stress." ${ }^{47}$ Nietzsche asks, again, that a choice be made to accept the burden of consciousness to say "yes" to life, which comparably yields a path to an attractive aesthetic-metaphysical end. Both the eternal revision and the eternal recurrence doctrines imply the Schopenhauerian premise that life is a constant struggle which incites a continuous striving to “overcome.” Burckhardt's eternal revision concept connects to two other ideas central to his greater historical project: the agon, about which we will have more to say, and the notion of the fragility of life. The perspective of both Burckhardt and Nietzsche was disposed to a governing "philosophy of difference." Burckhardt had once avowed, in a statement that would have been equally well-suited to the intellectual emanations of either Schopenhauer or Nietzsche, that "the great majority of mankind is trivial," and just as men are not all created equal (an erroneous supposition of the Enlightenment according to the two) so also various cultures are not all equal. While neither figure believed in veritable "golden ages" of the past, the cultures of the Renaissance and especially ancient Greece were seen as exemplars of the rich potentiality of humanity. There was, in Burckhardt's mind, a distinct lesson to be learned from the paucity, historically speaking, of cultures comparable to that of Greece. Historical-mindedness (through Anschauung) can relieve us of our petty egotism and Brobingnagian delusions; it can equally expose us to the mendacities hidden in the "veil of Maya" per objective consciousness. History, for Burckhardt, encompasses the spirit of momento mori, for its rare and exquisite artifacts offer us not only stark reminders of our own individual mortality but also of the fragility and frailty of even mankind's greatest achievements, including civilization itself. $^{48}$ 
The association of Burckhardt's and Nietzsche's historiography and Greek reception includes a shared "psychological” perspective. While Walter Kaufmann's pioneering study has addressed a good deal of psychological-philosophical issues pertaining to the philosophy of Nietzsche, it remains to investigate such an analogue Burckhardt's thought. ${ }^{49}$ In particular, Burckhardt's reception of "happiness" provides a window into the psychologically charged aspect of his historiography.

Though such an approach might appear at first glance unusual, Burckhardt's remarks on happiness are quite frequent in his later writings and additionally they help illuminate some of the historian's key ideas. ${ }^{50}$ It is useful to juxtapose the foregoing “eternal revision" topos with Schopenhauer's own comments on human happiness. In a passage from his The World As Will and Representation, a work which the otherwise anti-philosophical Burckhardt highly regarded, Schopenhauer offers the following devastating assessment of man's Sisyphean complex: ${ }^{51}$

We then see constant suffering without any lasting happiness. For all striving springs from want or deficiency, from dissatisfaction with one's own state or condition, and is therefore suffering so long as it is not satisfied. No satisfaction, however, is lasting; on the contrary, it is always merely the starting-point of a fresh striving. We see striving everywhere impeded in many ways, everywhere struggling and fighting, and hence always as suffering. Thus that there is no ultimate aim of striving means that there is no measure or end of suffering. ${ }^{52}$

Burckhardt repeats these sentiments in building his critique of the modern "eternal revision" ethic. His consonance with Schopenhauer's starkly anti-Leibnitzian position ("this world...which had better not exist at all") is grounded in an almost Malthusian perspective. ${ }^{53}$ The nature of material reality flatly precludes the achievement of universal or absolute happiness, for the reason that the human will is insatiable. Just 
as human striving is defined by a "ceaseless activity through higher and higher forms, till the final point, the seed, becomes anew a starting-point," the modern "eternal revision" impetus is likewise marked by an appetite for the continuation of a "constant struggle" that is repeated ad infinitum, for which "nowhere is there a goal, nowhere a final satisfaction, nowhere a point of rest.",54

Schopenhauer ends up with a final, nihilistic acceptance of the inherent hopelessness of the genuine achievement of happiness as well as a resultant determination to maintain an abstemious "denial of the will," and Burckhardt starts from the premise that happiness is an ignis fatuus in order to actively critique prevailing ideology. ${ }^{55}$ In his essay "On Fortune and Misfortune in History,” Burckhardt attacks the tendentiousness of modern historical judgment. Thus modernity judges the "goodness" of a given historical period or a specific historical culture based upon the imagined popular contentment that said society seems, according to we moderns, to exhibit. Such a verdict, Burckhardt argues, follows from contemporary society viewing itself as a culmination of the historical "progression" of culture and morality. And so Burckhardt, with a sense of sardonic self-awareness, states that it was therefore "Fortunate [for modernity] that the Greeks conquered Persia...fortunate that the Germanic tribes refreshed the world with new stock...[and] fortunate that Spain and Louis XIV were eventually defeated in their plans for world domination, etc. ${ }^{, 56}$ Modern ideology asserts that such paradigmatic shifts in history reflect the universal improvement of the station "the people," of the ineluctable promotion of universal happiness (read: "freedom") - insofar as these events can be shown to have helped produce the present-day "best of all possible worlds." And yet, 
Burckhardt continues, the calcification of historical judgment, e.g., the Greeks were "happy," Greece was "good," and so forth, patently disregards a wealth of unpleasant historical truths. ${ }^{57}$

"By an optical illusion," Burckhardt adds, with something of an aesthetician's air: We see happiness at certain times, in certain countries, and we deck it out with analogies from the youth of man, spring, sunrise, and other metaphors. Indeed, we imagine it dwelling in a beautiful part of the country, a certain house, just as the smoke rising from a distant cottage in the evening gives us the impression of intimacy among those living there. ${ }^{58}$

Burckhardt's impression of innocuous familiarity is meant to illustrate the tendency of modern historiography to reduce historical reflection to an unconsciously narcissistic act. Here he expounds an apparent rebuke of modernity's claims to the categorical benefits of science, including its celebrated ability to enhance general "efficiency" and to ease the prior discontents of less "developed" societies. ${ }^{59}$ Burckhardt's analysis of "fortune and misfortune" in history reflects the tone of Nietzsche's psychologism in the sense that it presents modernity's prevailing myths in light of their attempt to alleviate the "wounding essence" of life, to deny, as it were, the tragic spirit of the will. Accordingly

We pity for their unhappiness past ages, people, parties, creeds, and so on, which passed through long struggles for a higher good. Today we should like to see the aims with which we sympathize triumph without a struggle, and pluck victory without effort; and we transfer the same wish to the past. ${ }^{60}$

But this anestheticizing of history (and humanity), Burckhardt contends, is utterly deceptive. To discount the importance and veritable presence of struggle, "for life," is to close the doors forever on humanity's higher calling. Foreshadowing his important agonal theory for Greek reception, Burckhardt indicates that the reflective condition 
of Becoming as "struggle" presents man with a genuinely complete mosaic of ontological possibilities, since it is "only through struggle, at all times in all questions of world history, [that] mankind realizes what it really wants and what it can really achieve.",61

An additional implication of Burckhardt's critique of modern ideology in relation to his psychological-historical perspective includes attempts to use the idealized happiness of the present age and the reception of the past cast through the prism of this "happy present" to achieve a scientific classification of man's nature. The Enlightenment project conceived of history in particular as an area of research that would potentially yield empirical facts about the inner, "alienated" aspects of man. 62 "Happiness" became, through the use of both statistical sciences and the early codification of behavorial psychology, a way for various power ensembles to not only govern individual behavior, but even our very psychical underpinnings. With the modern ascension of reason, as Nietzsche observes, happiness is understood moreover as basically extrinsic to the natural world and to pre-civilized "nobility" (one might call it the master ethos). The ascension of Apollonianism ushered in the identification of happiness with "the good." Happiness was increasingly correlated with the equitability of a synthetic, nomothetic-type legislation of justice; it was consequently born of ressentiment directed toward non-egalitarian life - toward the ungovernable world-will. Historicism connected the teleological normalization of democracy and "inalienable" human rights over time to a grand therapeutic process which had resulted in the somatic "cure" of modernity, i.e. a state of "permanent, joyous well-being" or Heiterkeit, in Nietzschean parlance. ${ }^{63}$ Modern society, aided by 
the primacy of the historicist "happiness criterion," maintained not only an historically grounded sense of moral superiority, but even a certain sense of inner well-being. The net effect of the modern, historical-psychologizing drive was, Burckhardt contends, to both distort, and sanitize, our perception of the past and present and to inject historical understanding with deluded moral judgments. ${ }^{64}$ In this way the study of history, as Nietzsche likewise observed, acted as a handmaiden to modernity's ambition to reclaim happiness.

In order to better contextualize Burckhardt's historiography, it is useful to compare his ideas with those of the preeminent German historian of the first half of the nineteenth century, Leopold von Ranke (1795-1886). Burckhardt studied under Ranke in Berlin between 1843-1846 and his formative exposure to the Rankean "system" influenced the drift of his mature historiographical convictions - though Burckhardt would nonetheless eventually break significantly with Ranke. Felix Gilbert asserts that Rankean historiography was a "philological-critical” hermeneutics which attempted to "raise history to a "science." Ranke said of the study of history that it should capture its subject "wie es eigentlich gewesen" (as it really was). In the "constructive" sense, the "history as it really was" precept encouraged the development of history as a fully autonomous discipline. In this way, philology and other discrete fields such as the study of art could be expanded in their various exegetical capacities to include the study of the past. Nietzsche was analogously responsive to the project of adapting the disciplinary parameters of his own field (philology) to include historical content and related analyses. The core disciplinary consonance of these two thinkers is illustrated through their respective studies of the 
Greeks. Burckhardt's Greeks and Greek Civilization is a cultural historicalphilological study that follows, in part, the guidelines of a Rankean philologicalcritical method involving the close revaluation of primary sources. One notable exception to this tendency is that Burckhardt favors the revaluation of evidentiary emanations of culture as opposed to those of politics. Nietzsche's Birth of Tragedy is similarly a cultural philological-historical study whose method, or anti-method, is substantively comparable to that of its Burckhardtian predecessor.

While in the eighteenth century the French Enlightenment placed an emphasis on reason, progress and modern civilization, the German tradition was, contrarily, colored with self-doubt, a partiality for Kultur over Civilisation and rather backwardlooking (historically speaking) on the whole. By the midpoint of the nineteenth century however, the traditions of French and German Enlightenment reception increasingly acquired a favorable perception of the modern nation-state ideal. According to Burckhardt, Germany in particular, through the "perversion" of both Goethe and Herder, "saw the increasing power of the state not as an irrelevance (as it had been in the eighteenth century) but as an essential part of the same organism [of Kultur], the protective carapace which society created out of its own substance., ${ }^{, 65}$ The failings of the liberal-populist revolution of 1848 and the synchronous, centripetal forces of modernization and Volkism gave rise to a particular conception of nationhood that aligned with an overarching "Prussian" sensibility. In addition, the concurrent rise of scientism and the positive reception of nationalism by the middle of the nineteenth century in the German-speaking world tended together to affirm the soundness of the Fichtean-Hegelian conception of the nation-state as a genuine 
personification of an encompassing "universal spirit." Gilbert views the attendant Rankean claim that political history is revelatory of the "inner truth" of the world as grounded in the acceptance of a scientific-deductive historiography that heralds a particular post-Enlightenment, nation-state teleology. ${ }^{66}$

Burckhardt objected to this position in building his cultural history project. For Burckhardt, "the cultural historian does not want to learn from his sources the 'facts' of the past; he studies the sources because they express the spirit of former times. It does not matter, therefore, whether they are factually correct, whether they lie or indulge in exaggerations or inventions. ${ }^{67}$ Indeed, Burckhardt's political disillusionment, in addition to his related affection for Bildung as the phenomenalization of the self, in part confirmed for him a vision of a palimpsest of history. Through metaphor, as Hayden White has noticed, and the acknowledgement of the hermeneutics of discovery, history may be written and rewritten innumerable times. The apprehension of history, as Burckhardt was fond of saying, is akin to the experience of "poetry" - it is ultimately an aesthetic experience. 


\section{Elements of Heterodox Kantianism: Aesthetics and a New "Objectivity"}

\section{A. "We are the gazers and the gazed upon": Post-Kantian Cognitive Limits and Their Bearing on Historical Representation}

The historiographical culture of Basel, principally in the case of Burckhardt and Nietzsche, developed out of an interpretation of Kant concentrated in two basic premises: the importance of $d u t y$, and the notion of the unconquerable limitations of the human intellect. The historiography of Burckhardt and Nietzsche was nevertheless not solely a Kantian mindset. The point is that these two figures are working within a philosophical landscape whose general fault lines were first surveyed in a substantive way by Kant.

With regard to the recurrence of duty within the "Basel" philosophical tradition, both Kant's essay on Enlightenment and his seminal Critique of Practical Reason capture a common mood shared amongst the intellectuals of Basel who recognized the fragility of human relations and the inestimable role of culture as a "property of community... [as well as the attendant role of the ruling class] to carefully husband, hand down and protect" culture from any manner of dissipation. ${ }^{1}$ In a lecture given in 1877 in Basel, Wilhelm Vischer reiterated the sentiments of Burckhardt in his insistence that history is an instrument of education (Bildung) rather than a science (Wissenchaft). ${ }^{2}$ This emphasis accorded with post-Kantian ethics and with the dictum: "sapere aude!" that is, that we should dutifully strive to become genuine learners and teachers.

Vischer's investigation of the boundaries of human understanding reveals the common deflationary mood of this post-Kantian, Baseler heritage: 
Once we have become aware of the limits that the imperfection of man's sense and the deficiency and capacity for error of his character place upon the correct understanding and the faithful transmission of past events...can we still entertain the slightest doubt that in the realm of historical knowledge no absolute certainty can ever be attained ${ }^{3}$

Burckhardt and Nietzsche both assert what Ranke, Hegel and the various other figures of German objective historicism refuse to admit: the inexorable limits to absolute historical certainty. ${ }^{4}$ The Kantian conception that the world is (partially) mind-contingent motivates the apprehension of these limits. While mainstream Kant reception tends to accept Kant's idea as an affirmation of the dual sovereignty of metaphysics and the empirical sciences (this was, after all, one of the self-proclaimed goals of Kantian philosophy), in the case of Burckhardt and Nietzsche, there conversely exists a need to forge a new manner of an"objective" aestheticmetaphysics in light of the perceived confinement of the world within the "prisonhouse" of pure ideality. ${ }^{5}$ Kant reminds us of humankind's Promethean spirit, of our undaunted longing to wholly interrogate the world - to lay bare the quiddity of existence for all time; yet, Kantian philosophy admits also of the discordance of human fallibility, of the hopeless finitude of our faculties and of even the "crooked timber" of our being. ${ }^{6}$

Burckhardt's and Nietzsche's own philosophical peregrinations share a common crossroad in the philosophy of Schopenhauer. Schopenhauer functions primarily in the present narrative as a supreme ironist. He is a theorist who touts the value of preserving life in the face of its inherent meaninglessness, of selfconsciously denying the world-will though our existence renders us finally powerless to oppose it, and of confessing the impossibility of the enterprise of philosophy itself. 
Accordingly, Schopenhauer is one of the first - if not the first - modern antiphilosophers. Schopenhauer abnegates, in large part, the central doctrines of occidental philosophy by openly denying the inherent rationality and the practical comprehensibility of the world. His reading of Kant - and let us make no mistake, his philosophy is entirely an addendum to Kant - is, to appeal to Derrida, a "dissimulation of the woven texture" of Kantian philosophy. ${ }^{7}$ If he does not openly “deconstruct" Kant, Schopenhauer at least essays to dismantle his various Cartesianrationalist parapets. Here is Kant or even western philosophy as a whole turned on its head, ripe for revaluation - or, the inversion of all values. Through the conduit of Schopenhauer, heterodox Kantianism accesses wisdom in naiveté, knowledge in nescience, truth in falsehood, and the affirmation of life in human misery and suffering. There is a fundamental irony in this process of constructive dismantlement itself, of unraveling a "web that envelops a web, undoing the web for centuries.", Burckhardt and Nietzsche both apply themselves sedulously in building a new historiography from a "negative origin," that is, from the wholesale erasure of erstwhile historical truths. Burckhardt's Greeks are indices of a post-Kantian aesthetic turn that subversively interrogates the legitimacy of conventional narrativerepresentational models by raising historiography to the level, to borrow a phrase from James Porter, of an "allegory of conceptuality." ${ }^{\text {9 }}$ By directly confronting the limits and contingencies of human existence, of our ineluctable human-all-too-human condition, Burckhardt and Nietzsche devise a pathway to new and unfrequented vistas of self-examination that encompass, finally, the conceptual fusion of will and representation. 
Nietzsche's pronouncement from Birth of Tragedy on the deeper, inner synergy between will and representation, viz., that of historian and the narrative conceptualization of history itself, is in consonance with the greater aestheticizing and anthropologizing facets of Burckhardt's own historiographical convictions.

We are the will, we are figures of a vision; wherein lies the connecting thread? And what are living nerves, brain, thought sensation? - We are at once the gazers - there is nothing besides the vision to gaze upon - we are the gazed upon, merely something gazed upon - we are the ones in whom the whole process begins afresh once more. ${ }^{10}$

The idea that history consists of a perceptive "double-orbit" - that it comprises the composite Janus-face of "gazer" and "gazed upon" - is a defining characteristic of Burckhardt-Nietzsche historiography. This schematic arises out of a deflationary world-model, inspired by Schopenhauer, which posits man in hopeless subjugation to will. Schopenhauer contends, to this end, that the will, considered purely in itself is:

Devoid of knowledge, and is only a blind, irresistible urge...Through the addition of the world as representation, developed for its service, the will obtains knowledge of its own willing and what it wills, namely that this is nothing but this world, life, precisely as it exists. ${ }^{11}$

Through Schopenhauer, history is anthropologized by way of its deflationary function. In this context, history is bound up in the circularity of the human condition, in the vicissitudes of the invincible will - and too, paradoxically, in its own objective purposelessness. Nevertheless, despite their fundamental philosophical agreement with Schopenhauer that representation qua the formal conceptualization of history is an instance of the will obtaining knowledge of "its own willing," Burckhardt and Nietzsche - particularly through their respective Greek receptions - attempt to overcome Schopenhauer's final, nihilistic conclusions with something like a 
metaphysically-affirming, new historical "objectivity.",12

The Burckhardt-Nietzsche tradition partakes in a linguistic-conceptual heterodoxy that is in many ways a hallmark of its self-interrogating character. Burckhardt and Nietzsche both suggest that their own modes of historical scholarship, though decidedly anti-scientific, counter-empirical theories, are nonetheless emanations of a higher "objectivity." One could, as Nietzsche proposes, "think of a kind of historical writing which would not contain a drop of common empirical truth and yet be entitled in the highest degree to the predicate "objectivity." ${ }^{, 13}$ Both thinkers regard history, in its elevated aspect, as a medium through which the "eternal and perdurable" features of humankind are refracted back to the mind itself; history is the locus for which the self comprehends the whole as a continuum of selves. "The 'objective' historian is not concerned with the truth content or moral import of history. He does not write to represent the past but to phenomenalize an aesthetic historicity, that is, to allow an illusory facticity of appearance to show itself as if it were a projection of the primordial will." ${ }^{14}$ Here we see an inversion of objectivity (and also a gateway to common aesthetic ventures) and in turn the wholesale dissection and dismantlement of historical representation itself. Unlike the case with Schopenhauer, Burckhardt and Nietzsche's common acceptance of the "negative origin" of art - viz. of nature's fundamental indifference to all human tribulations and to moreover, the dramatic materialization of human history - is not accompanied by a sense of ascetic resignation nor an ultimate renunciation of the will to live. ${ }^{15}$ Burckhardt's and Nietzsche's historiographical projects intend instead to operate, as both figures make clear, in service to "life," that is, in accordance with the 
quintessential contradictoriness of being. ${ }^{16}$ Both theorists support an impression of history in direct contradistinction to the predominant scientification of historical knowledge, that is, the vitiating spirit of scientific objectivity. The historicist appropriation of scientific methods with which both thinkers are in direct dispute accepts a peculiar point of absolute indifference. Nietzsche compares such a perspective to the cold indifference of nature: common objectivity is, consequently, an instance of nullification since it presupposes a world bereft of its human texture of any semblance of a "gazer." Burckhardt and Nietzsche both suggest that perception, by its very nature, is an aesthetic act. To perceive the world is to concurrently synthesize the sensory manifold of one's surroundings and to impress upon these same surroundings the tincture of our own representation. The act of human perception is therefore an intrinsic falsification; in Nietzsche's words, it is an "error" insofar as "error is the condition of life." ${ }^{17}$ Yet the illusory quality of perception - of the narrow compass of remembrance (and similarly forgetfulness), of the continuous reconstitution of reality in all of its diverse and too in its dissonant forms - is part and parcel of the greater act of "art in the service of illusion.." ${ }^{, 18}$ In this way man "spins his web over the past and subdues it, so his impulse to art expresses itself." ${ }^{\prime 19}$ Writing history consequently involves a weaving of the whole out of the isolated, where the whole is not by its nature immanent in the world - the past, in other words, is not a standing reality to be unearthed, but rather a "dramatic presentation." History is an artifact of perception whose dramatic emplotment is imposed by the very appearance of the self. ${ }^{20}$ Historical objectivity in the BurckhardtNietzsche iteration is therefore a "poetic" sense of the past. Whereas in mainstream 
Kantianism aesthetics are often prone to objectification, it is conversely the case here that (historical) objectivity becomes fully aestheticized.

\section{B. The Aesthetic Interlude: Counter-Concepts and Aesthetic "Play"}

While Burckhardt's aesthetic historiography resembles aspects of the ideas of Kant and also Schopenhauer, his aestheticism is nevertheless best understood as moving beyond Kantianism in certain respects. Kantian aesthetics were a radical departure from conventional aesthetic theory, dating back to Plato's denunciation of poets, in that Kant attributed an unprecedented degree of independence and philosophical value to art qua aesthetic judgment. ${ }^{21}$ In his Critique of Judgment, Kant maintains that beauty is not inherent in a given objet d'art but rather it is the subject which impresses, through aesthetic judgment, a sense of the beautiful upon this object by way of aesthetic contemplation. Kant is also unambiguous in his effort to delineate aesthetic judgment from the province of rational judgment:

In order to discern whether something is beautiful or not, we do not submit its representation to (the faculty of) understanding for cognition, rather we relate it by means of the imagination (possibly connected to understanding) to the subject and its feeling of pleasure and displeasure. The judgment of taste is therefore no cognitive judgment, hence not logical, but aesthetic, meaning that whose determining ground can only be subjective. ${ }^{22}$

By characterizing aesthetic judgment as at once subjective and counter-rational, Kant distinguishes between the affirmation of subject by way of a universalizing sense of the beautiful (aesthetic judgments are governed by the transcendental structure of our faculties) and that of the primary, "form-making" function of reason. Whereas our apprehension of the beautiful is not purely subjective because beauty "lays claim to a universal [viz. transcendental] delight," the aesthetic judgment "cannot claim that 
kind of universality that is only possible for rational judgments"; aesthetic judgments are not, in other words, of a piece with a priori knowledge because they are intersubjectively contingent. ${ }^{23}$ Kant's provocative attempt to square the higher, universalizing aspect of beauty with the counter-rational essence of aesthetic judgment, involves the codification of what he calls "subjective universality." True universality, as Kai Hammermeister has pointed out, is only accessible according to Kant by means of concepts, that is, "something that is validated by its logical necessity." ${ }^{24}$ Aesthetic judgments are, contrarily, incapable of such logical reconciliations. In the case of aesthetics, Kant claims that it is impossible for the mind to achieve a manner of cognitive universality since judgment never achieves genuine understanding (wherein the unity of the visual manifold is encompassed in a formal concept). In fact, Kant fashioned the notion of the "aesthetic idea" as the canonical failed effort to submit the sensory manifold to a single cohesive concept: "By an aesthetic idea I mean that representation of imagination that incites much thought, yet without any thought, i.e. concept ever being adequate to it and that can therefore not be reached and rendered comprehensibly by any language." ${ }^{25}$ For post-Kantianism, aesthetics accordingly signify a sense of conceptual indecipherability and of the limits of the form-giving function of reason. Moreover, the counter-rational and subjective nature of aesthetic judgment elucidates the potential "infinite interpretability of the work of art" and more so, that of life. With post-Kantian aesthetics, particularly in the case of what I will classify as Burckhardt's reversal of Schopenhauer's aesthetic turn, the aesthetic mode qua history counteracts various positivist historiographical tendencies by employing a model for historical studies that is at once counter- 
conceptual (since it is believed that formal conceptual taxonomies work to annul the essential principium individuationis of their subject) and, as will be shown through the example of the sublime, sufficiently "life-affirming."

The aesthetic turn in modern German thought, particularly in its counterEnlightenment variant, has been characterized as an attempt to overcome the postKantian "situatedness" of human existence. Terry Eagleton, for example, has observed that while mainstream receptions of Kant tended to routinize the process of human understanding as a reflexive cognition of the relation between the world and self, aestheticism per counter-Enlightenment ideals, by contrast, accentuated the experience of "one's own" point of view and offered a challenge to prevalent modalities of representation. ${ }^{26}$ In a related study, Allan Megill has argued that modern aestheticism is not indicative of a separation from the "real world" of nonaesthetic objects, but rather that aestheticism connotes an "attempt to expand the aesthetic to embrace the whole of reality.... a tendency to see 'art' or 'language' or 'discourse' or 'text' as constituting the primary realm of human experience." ${ }^{27}$ Nietzsche has, in this vein, acknowledged that the world is "justified only as an aesthetic phenomenon" and that the artist sees "nothing as it is, but fuller, simpler, stronger" (Will to Power 800). The artist possesses an ability to transmute reality through creativity, through the Schillerian-type "play" of the reconfiguration of archetypal constituents of representation. Such a venture does not, however, offer insight into trans-phenomenal truths. Instead the aesthetic drive in counter-Enlightenment thought is ironically cognizant of its illusory basis. Burckhardt and Nietzsche make an effort to consciously formulate "myths." 28 The imaginative ability to transcend our immediate 
and mundane existence (ekstasis) is actualized in this setting through what Megill terms a "freed intellect":

One that, precisely because it recognizes the illusory status of concepts, will be able to use them in a truly creative and artistic way. [The freed intellect] is 'no longer led by concepts but intuitions.' A free play of intellect begins: one that does not lead into 'the land of spectral schemata, of abstractions,' but delights rather in play for its own sake, in bringing forward 'forbidden metaphors' and 'unheard-of combinations of concepts.' In short, [this process] envisages not the destruction of the conceptual world but rather its deconstruction - that is, its transformation into a realm of aesthetic illusion and play. ${ }^{29}$

Aestheticism undercuts the limits of possibility imposed by Kantianism in its empirico-deductive and ontologically finite aspects by promoting the "fullness of existence" through the negation of the imposition of the logical determinedness of the world - and of man by extension. Albert Salomon depicts Burckhardt in this respect as a theorist who "transcends" history by rejecting the conventional categories of historical-social morphology through the conception of an aesthetic-metaphysics. ${ }^{30}$ Burckhardt confronts the quasi-secular, progressive ideas of mainstream nineteenth century theory exemplified by, among others, Hegel's dialectical agnosticism, Marx's dialectical economism, Comte's positivism and Spencer's evolutionism. These thinkers share a belief in the rationally comprehensible meaning of history, in the general, "positive" drift of history and also finally in the "merely instrumental role of the individual in the process of history" (Salomon). Methodologically, they commonly advocate a procedure of historical inquiry which "isolates particular tendencies within the universal whole which serve as a foundation upon which to construct the unity of a historical system. They attain order and unity by referring human action and thought to an abstract principle which lends history the character of 
a purposeful, moving spectacle." History thus becomes a sort of "philosophical totalitarianism which forces all the actions and thoughts of man into a predestined pattern." ${ }^{31}$ Burckhardt's aestheticism defies these premises through the formulation of plastic conceptual-historical rubrics which render human situatedness "transparent [as] imaginative contemplation." 32 The territory of the aesthetic is not that of reality but rather ideality: "the true ideality - to use reality in such a way that the truth of the imagination creates the illusion of reality" (Goethe); it is a terrain of "elevated normalcy" in which the individual is liberated from mortal subjugation to the inexorable march of History, viz. the world-will. As Bergson, who crafted an analogous, aestheticized notion of history, once noted: "[works of art] constitute a reality of their own, a second creation... They arise from mysterious vibrations communicated to the soul. What is released by those vibrations has ceased to be individual and temporal and has become symbolically significant and immortal., ${ }^{, 33}$ Burckhardt's aesthetic turn, as Salomon has discovered, was towards a postmetaphysical disinterestedness. The aesthetic returns history to its imaginativecontemplative roots, that is, its Herodotean origin, and cultivates a redefinition of “objectivity" from a perspective of ontological indifference. Thus we may finally imagine history as comprising a "purposiveness without purpose." (Kant) In his postmetaphysical outlook, Burckhardt intends to shift the focus of history away from the ontological totality of God - or a God-Logos, for that matter - and toward instead the subject of man. ${ }^{34}$

\section{The Sublime and the Affirmation of Life}

The appropriation of the aesthetic category of the sublime, while common to 
heterodox Kantianism, experiences a significant departure from its nihilistic Schopenhauer roots in the Burckhardt-Nietzsche variant. In part, Kant's assessment of the sublime follows Burke's delineation of it from the beautiful (an indubitable source of pleasure). Like the beautiful, the sublime is subject-induced: there are no sublime objects, but only sublime states of subjectivity. ${ }^{35}$ The sublime is, unlike the beautiful, a by-product of a sense of inner, existential dissonance. It encompasses a state of anxiety in which the finite self directly interrogates its own finitude (and by analogy, its inevitable annihilation) through the contemplation of that which is suprahuman. Kant cites the image of "thunderclouds piled up in the sky....volcanoes in all their destructive power, hurricanes with the destruction in their track, the boundless ocean rising in anger," as phenomenal inducements of a sublime state. ${ }^{36}$ Because the sublime is ostensibly an aesthetic experience, it cannot be circumscribed by definite language, just as Kant means to imply with these specific examples. As Hammermeister puts it, in more precise Kantian parlance, "imagination will not be able to synthesize the sensual manifold of [such] an object into a unity." ${ }^{37}$ Unlike the beautiful, however, which is likewise immune to definite categorization, the sublime is nevertheless experienced in a deeply visceral and rooted way that speaks to its inborn ontological connotations. Heidegger, we recall, accordingly maintained: "Being is what we understand in a completely indefinite and yet supremely definite way." 38 The sublime conveys the generally entropic mood of heterodox Kantianism as a common recognition of man's epistemic and ontological finitude recontexualized within a greater "allegory of conceptuality," namely, the conceptuality of representation. 
Burckhardt's most obvious specific appropriation of the category of the sublime into his larger historiographical project is manifest in his development of Greek pessimism. It is often the case that scholars regard Burckhardt's pessimism as a purely Schopenhauerian topos. In fact, Burckhardt's subversive exploration of Greek pessimism operates instead as an inversion of Schopenhauer's nihilism which is reminiscent of Kant - and yet its problematizing aspect nonetheless advances this particular exploration beyond the immediate scope of Kantian philosophy. If one understands the confrontation of the human-will with the world-will in the philosophy of Schopenhauer (a distinction which is never adequately reconciled) as the archetypal encounter of the individual with the redoubtable formlessness of the infinite, then it stands to reason that Schopenhauer's decisive injunction to "deny the will" entails precisely a kind of existential self-immolation - a surrender, that is, to the power of the sublime. With Kant the sublime presents an avenue for existential redemption and human transcendence. He asserts that the human capacity to conceive of the infinite is, in its pure ideality, evidence of man's ability to transcend the confines of the senses by way of the aesthetization of reality. Kant thus goes beyond Burke in his reassessment of the transformative potential of the sublime. For Kant, the sublime consequently becomes an unconventional source of human empowerment and an affirmation of human dignity:

The irresistibility of it [nature] forces us on the one side to acknowledge our physical helplessness, but on the other side reveals a faculty of estimating ourselves independent of it. On this faculty rests a self-preservation of a very different kind as that which can be challenged and endangered by nature, so that humanity remains unhumiliated in our person, even though man would be defeated by that force. ${ }^{39}$ 
Kant thus prompts an epochal shift in intersubjevivity theory. He does not posit the existence of a world without man, i.e. a post-Redemptive world, but rather a mode of existence independent of any "object" itself - a world comprised solely of a subject; Kant constructs, in other words, an ontology of mind. His notion of the sublime rouses in this fashion man's latent "power of resistance." The acclamation of both human resistance and human nobility is correspondingly captured in the historographical projects of Burckhardt and Nietzsche through their overt celebration of human ontology. Burckhardt's Greeks encapsulate a distinctly counterEnlightenment exaltation of the human condition which underscores its immutably tragic element. For Burckhardt, history writ large comprises an extension of the Kantian sublime state in that the act of conceiving history necessitates an encounter with an undifferentiated - and infinite - past. Moreover, such an endeavor should work to elevate humanity on the level of the revitalization of self-conception. History, as Burckhardt once remarked, "is for me, for greater part always poetry." 40 In the Burckhardtian view, history is an aesthetic expression with a purposive, cathartic significance that connects humanity's sense of being with our retrospective attempt to adequately schematize being. In this way, Burckhardt presages something like the emergence - to recall Heidegger's project of an historical Dasein. 


\section{The Greek Lectures}

\section{A. A Herodotean Method: "Mythistory"}

Burckhardt's Greeks and Greek Civilization lectures (first presented in 1869 and published only posthumously) represent the consummation of the author's dissenting cultural-historiographical method. Predictably, Burckhardt's Greeks garnered disapproval in contemporary German academic circles in a way that parallels the mainstream response to Nietzsche's equally outré Birth of Tragedy (1872). Just as the concurrent reception of other, subversive emanations of modernism, like Monet's early oeuvre (with which Burckhardt's and Nietzsche's historical "perspectivism" shares something of an aesthetic kinship), which incurred widespread critical condemnation for its absence of "devotion to form and respect for the masters," so too the anti-academic Greek receptions of Burckhardt and Nietzsche were dismissed from an early point on account they divagated from normative practices. The classical philologist, Ulrich von Wilamowitz-Moellendorff, who was highly critical of both Burckhardt's and Nietzsche's Greek studies, saw a strong thematic correlation in their works. He condemned Burckhardt in particular, arguing that he "ignored what the scholarship of the last fifty years has achieved in relation to

sources, facts, methods and approaches" and that "the Greece of Burckhardt no more exists than does that of the classical aesthetes, which he could rightly have attacked fifty years ago."

Such critiques of Burckhardt fail to grasp the aestheticizing tendencies in Burckhardt's historiography and the degree to which such inclinations invigorate his 
critique of modernity. Indeed, Burckhardt understood the propagation of myths through history as tokens of an immanent, temporally contingent "truth." Foucault says, to this end, that "the world continues [a] secret existence though a host of errors and phantasms," and Nietzsche likewise remarks that the "true world" is a fable consisting in the "history of an error." The perception that "errors" can potentially yield fruitful information related to non-normative forms of knowledge is at the heart of Burckhardt's chimerical Greeks. In the preface, Burckhardt admits that his impression of antiquity is as unlikely to have existed as the equally fanciful renderings put forward by Winkelmann, Lessing, Goethe and Schiller. And yet Burckhardt's inward-looking tendencies and his recognition of the limitations of human knowledge are qualities that effectively separate his Greek reception from that of the classicists before him. Like another, later, avid Schopenhauerian Wittgenstein, who was keenly interested in the various crevasses in the levee of language, those times when "language goes on holiday," as he put it, Burckhardt concerned himself analogously with looking "beyond the margins," so to speak, of historical representation. The Greece of Burckhardt's lectures is equally the byproduct of the aesthetic-creative vagaries of its creator as well as that of a social dreamscape - of a collective, unconscious mythology: "Do you know the terror of he who falls asleep? To the very toes he is terrified, because the ground gives way under him, and the dream begins." Burckhardt intends for his own study to offer a glimpse into the "vital forces, both constructive and destructive, that were active in Greek life."3 His rendering bespeaks an attention paid to the "mystery and poetry," i.e. the empirically inaccessible or trans-representational aspects of the Greeks. ${ }^{4}$ Burckhardt 
is thus operating within a representational schematic that he recognizes as a markedly Greek mindset. His analysis reverberates with echoes of a Greek enigmatic sensibility, a Delphic sensibility; nowhere is this sense of inner tenuousness and methodological dissension more apparent than in the case of his perspectivist method and his peculiar reception of Greek myth.

Burckhardt's perspectivism is most apparent in the case of his Greeks and Greek Civilization among all of his major historical studies. While it is nonetheless true that his earlier works, e.g., The Age of Constantine the Great (1852) and the much-celebrated The Civilization of the Renaissance in Italy (1860), sustain a novel sense of methodological skepticism, inner plasticity and a partiality for historical "free invention," Burckhardt's Greeks represents a definitive stage of the author's historiographical heterodoxy. Of these early publications, his study of Renaissance Italy employs the most paradigmatic use of the author's so-called "three powers" conceptual schematic (the state, religion and culture). In Reflections on History Burckhardt would later admit that such architectonic devices are quite arbitrary: "the division [of the 'three powers'] is a mere device to enable us to cover ground... any historical study must proceed in this way." Though there is in The Civilization of the Renaissance in Italy a sense of the "variable and the free," of the spontaneous methodological aspect common to Burckhardt's cultural-historical approach at large, there is too an impression that the essential yet "arbitrary" formal framing elements of this study in a subtle way limit the very (albeit idealistic) freedom of interpretation to which Burckhardt aspires as a cultural historian. In this study, Burckhardt strictly delineates the state, religion, and culture from one another in a way that, despite the 
author's conceptual ingenuity and daring, seems thematically preclusive in comparison to his later approach per the Greeks. Like his work on the Greeks, Burckhardt's Renaissance study uses a synchronic method. When Burckhardt regards the Italian commune as a "work of art," he intimates that "the state" - a discrete and relatively well-defined entity in its own right here - interacts synchronically and reciprocally with religion and culture. In this fashion, for example, the Renaissance individual develops out of the dialectical relationship of the state and culture. By contrast, Burckhardt's Greek lectures are absent such clear and distinct "reciprocal actions." The former tripartite division of the "three powers," though certainly still discernable in a vestigial form in his Greeks, comprises the singular object of "culture," which is here, at this later stage, less encumbered by formalistic concerns and closer to the elliptic and aleatory qualities that Burckhardt consciously sought to realize, as evidenced in his Reflections on History. ${ }^{6}$

Burckhardt's interest in the "spirit" of the Greeks admits, as he says, an apprehension of the "eternally valid and universally intelligible...the perdurable" aspects of the Greeks. ${ }^{7}$ The "eternal" aspect of the Greeks encompasses, in this case, the "higher" (usually aesthetic) developments of Greek culture - the "base-chord" of the spirit of modernity. In light of his understanding of history as characterized by "continuous flux" and the inadequacy of the concept-form to sufficiently capture this inherent fleetness and inscrutableness, Burckhardt approached the Greeks from "many sides" so as to render an impression of the typical yet "unintentional" and the apparent yet unconscious aspects of antique culture. ${ }^{8}$ "The life of history, always unfolding between an origin and an end, in continuous movement and change, is the 
material to which Burckhardt applied his new historical method." ${ }^{9}$ In this way the variable pivot of the point-of-view of the historian simulates the multifarious flux of history with remarkable effect: "Never were the aspects of human life presented in forms so manifold and in hues so parti-colored as in the kaleidoscope which Burckhardt holds to the eye of the reader and slowly turns in his hand."10

When Burckhardt speaks from time to time of learning to know the "eternal Greek" he means something quite removed - in an epistemic sense, though not always in a thematically dissimilar way - from Hegel's conception of Geist. Hegel exhibits, in my reading, an assurance in the representational soundness (as induced by the universality of reason) of historical study. Hegel is content to answer not only the basic "how question" of history which involves the formal tabulation of various empirical facts in convenient, diachronic cause-effect relationships, but he moreover alludes to the formulation of a solution to the tenebrous ontological "why question" of history. By contrast, Burckhardt's analysis lacks the Olympian air common to Hegel in dealing with the "recurrent, constant and typical," viz., "things of the spirit" concerning the Ancient Greeks. Though both theorists adopt a common dialectical approach to history, the Burckhardtian method is nevertheless driven by "unconscious revelation” (Oswyn Murray’s term) - by a mnemonic-literary, “involuntary recollection": 11

Cultural history is primarily interested in belief and attitudes, rather than events...It does not matter whether stories which it uses are true, as long as they are believed to be true. And even a forgery is an important piece of evidence for the period that perpetrated it, since it reveals more clearly than a genuine article the conceptions and beliefs about the past of the age that created it. (Greeks, Introduction, p.5) 
Burckhardt's historical "why" is thus the reflective "why" pertaining to Greek selfperception. ${ }^{12}$ Why, in other words, did the Greek narrative construction of reality take the form that it did? In an effort to answer this question, Burckhardt turns to an examination of Greek myth.

Joseph Mali has identified Burckhardt as the preeminent "mythistorian" of the nineteenth century, meaning that Burckhardt recognized the primary importance of "ideological fabrications" in the formation of a given cultural Zeitgeist. ${ }^{13}$ Mali asserts that while "most historians [still] tend to dismiss myths as false histories," Burckhardt and likeminded mythistorians (Nietzsche is also identified by Mali in this context) understood these inventions as the revelation of deeper, subjacent "truths" - echoes, that is, of a persistent Greek spirit. In the same way, the contemporary Higher Criticism of Renan, for instance, treats myths as serving to "pass into identity itself" so that even though mythical stories might be factually erroneous, they are nonetheless palpably - and practically - "true"; they are, that is, "effective insofar as they are affective." ${ }^{14}$ Freud, who deserves equal consideration as a mythistorian, similarly identified the mythic roots of various totemic practices (and oftentimes these alleged historical practices were mythical constructs in themselves) as characteristic of an unseen historical psyche. In this way, the perception of a fictive, originary act of parricide serves as a force in the Freudian schematic that actively shapes the functional reality of a given society - of the spirit, moreover of a people. Burckhardt recognizes the place of myth "not as an explanation of the world but as an expression of how the people perceive it." Myth provides the basis for a particular narrative construction of reality. Because myth operates according to a dialectic of 
unconscious revelation, the myths of the Greeks reveal a great deal about their unspoken psychical temperament, particularly in the case of Greek pessimism (the implication here is that a strict Rankean empirical examination of Greece would overlook such "hidden" attributes). Burckhardt's analysis highlights the "somber" facet of the Greeks in a way that had never been achieved in prior studies and at the same time, his mythistorical contextualization of Greek pessimism tends to humanize these various "dark" traits by revealing their corresponding (and sometimes startling) inscription in the modern psyche.

Mali furthermore identifies Burckhardt as adhering to an overall "Herodotean methodology." ${ }^{\prime 15}$ Burckhardt not only accepted the predominance of the mythicalnarrative construction of reality as it pertained to Greek perception, but he additionally infused his own reality-construct qua historiography with certain mythic ideals. Burckhardt's history is a deliberately imagined history. The recapitulation of a "Herodotean methodology" in his Greek studies reveals an inherent opposition to Thucydidean (read Rankean) historiography.

Crucially for Burckhardt, it was Greek historiography that preserved the mythological tradition - most notable in Herodotus' composition of oral stories in his History. Burckhardt elaborates and justifies the Herodotean methodology of mythistory against the Thucydidean opposition, in terms that clearly assert the primacy of his own 'cultural history' over Ranke's 'political history.' 16

Herodotus' prefatory comment, "my duty is to report all that is said; but I am not obliged to believe it all alike - a remark which may be understood to apply to my whole History" signifies the original mythic turn of a history which does not commemorate a factual past - "how things were" - but rather the mythic narrative of 
a subjective perceiver. $^{17}$

Burckhardt's historiographical kinship with Herodotus also applies on the level of their related evaluation of sources. Burckhardt's Greeks showcases a novel hermeneutical reassessment of classical texts which extends to a reconsideration of varieties of historical sources. His Greek lectures utilize Pindar and Pausanias as much as The Athenian Constitution or Works and Days. Burckhardt's use of traditionally underrepresented classical sources afforded him a convenient avenue for interpretive unconventionality. ${ }^{18}$ Burckhardt extends the ambit of his "textual" inquiry to include "not only what is written down," but "every" extant fragment of the Greek past, including "buildings and the visual arts most of all."19 This shift in methodological perspective indicates Burckhardt's status as a vanguard for an expansive and multi-sided historiography. The specific, inter-disciplinary quality of his Greek study furthermore foreshadows his shift in focus from the study of cultural history to the discipline of art history, a field which Burckhardt helped pioneer. The heightened aesthetic element of Burckhardt's lectures, including his penchant for representational "play," the "free and flexible" nature of his perspectivist method, and the premium he places on a Herodotean "free invention," on Greek myth and the "unconscious revelation" of ideas, all point to the historiographical unconventionality of his Greek reception.

The Herodotus-Thucydides dichotomy represents an highly original periodization of the post-philosophical, post-agonal decline of Greek society to which ascribed. Mainstream Greek reception venerates the "golden" fifth century of Greece as a zenith of western thought and culture, punctuated by the emergence of Platonic 
philosophy; Whitehead later famously proclaimed to this end that the whole of Western philosophy is but a series of footnotes to Plato. Burckhardt and Nietzsche conversely view the emergence of Greek philosophy in its Platonic codification critically. For Burckhardt, philosophy does not represent the irrepressible means to the "higher" end of modern consciousness; rather, through its historical deconstruction, philosophy becomes uniquely vincible. We may see it finally as a mistake. Philosophy attempted to alleviate the "passionate...eternal discontents" of the Greeks by placing a confidence in the authority of "factual" representation, i.e. "the form." ${ }^{20}$ While such efforts were born from an attempt to release man, in part, from his subjugation to a world-will, viz. to nature, they conversely engendered an entirely new kind of subjugation to reason itself.

\section{B. The Genesis of Concept-Mindedness in Greece: Democracy and Vitalism}

For Burckhardt, philosophy marks the beginning of the hegemony of western concept-mindedness, the formalization of "morality," the vitiation of the agon and the attendant democratization of Greek society. In the allegorical Theogony, Hesiod emblematized the dangers of philosophy, of the epochal rational ordering of the world, through a grand narrative of the cosmos in which the elemental, undifferentiated (i.e. un-cognized) forces of Chaos ("void") among a litany of other primal forces, each submit to a successive narrative-anthropomorphization and are thereby brought under the ever-growing dominion of human reason. Hesiod's account is noteworthy for its anti-teleological drift. The appearance of reason (or pre-reason) 
does not signify an epochal triumph but instead the attenuation of a cosmic speciesbeing, of the dissolution of the wonderment and mystery of the world. The emergence of Plato equally marks the inception of the "demolition of myth" - for which Thucydides is seen as a prominent, "literary" emissary. Whereas Herodotus' "mythistorical" account of the Persian wars is, for instance, noteworthy for its absence of any real sense of an historical objective "good," Thucydides' description of the Peloponnesian War conversely expresses a greater didactic, even moral, purpose. Once the notion, for instance, of kalokagathia, "formerly an idea simply based on the real aristocratic and agonal way of life" fell into the hands of the philosophers, it was consequently "subjected to a complete purge in the name of ethics." And where kalokagathia had once,

described a kind of existence, its place was now taken by a means of acting on others, in fact of 'improving people,' and this became the yardstick applied to human beings and institutions; but Socrates, and those who spoke in his way, were using it to express a new ideal, and leaving reality to get along as well as it could. It was no longer the noble free individual they had in mind, but the citizen in general, and soon mankind as a whole. ${ }^{21}$

To take it further, the Socratic injunction to "know thyself" and, Oedipus' astonishing revelation that "man" was the long-sought solution to the riddle of the Sphinx, are each representative instances of the universalizing quality of the concept-form taking hold in Hellenic culture. To know thyself in the period following the agonal age is to know thyself concretely as categorical Man - as a contemplative, social (pace Aristotle) and "moral" being. By the same token, Odepius, as the analysis found in the Poetics makes clear, is a man - per the answer to the Sphinx - in the common sense; he elicits pathos in an audience for the very reason that we imagine ourselves 
to share an infrangible fellowship with him. We descry in Oedipus a reflection of ourselves, of our own wants and desires, of our human fallibilities and tribulations. In the alembic of philosophy, Oedipus is transmogrified into the everyman.

The new Greek attitude at this time was, in Burckhardt's mind, underlined by the "increasing thrust of democracy."22 Philosophy nurtured an understanding of justice that contradicted the basic premises of the prior will-driven agon; it presented the notion of human empathy - and likewise compassion, benevolence, "meekness" (Nietzsche) and the like - within a framework of universal, "human" triumph. The very narrative construction of history teemed with a teleological significance that reflects the ontogenetic birth of reason and the submission of Tyche (Fortune) to human ratiocination. Plato, for instance, reifies this idea in the classic allegory of the cave. Beginning in late fifth century, Greek society canonized "the "good" as the pursuit of obedience to the rational construction of reality. At the same time that philosophy formalized an essentialist, categorical man, it deemed that man's purpose consists in his unremitting exercise of reason, in his indefatigable quest for philosophical "truth" and - by extension - in his unique capacity to be moral. There was, according to Burckhardt, a corresponding impulse born at this time to objectively "improve" man in accordance with the precepts of a rationally-ordered good life.

Burckhardt hardly veils his contempt for democracy and democratic principles at large. The majority of his comments contained in the elegiac "Fifth Century" lectures (which comprise a significant portion of his entire Greeks) are an unambiguous invective aimed at modern democracy and modern culture. Burckhardt 
understands democracy, in both its antique and modern instantiations, as fundamentally at odds with the vitalistic potential of the individual. "For a long time in Athens the fiction was upheld that democracy was always bound up with "noble excellence"" and yet, Burckhardt relates, democracy contrarily inspired a relaxation of the very conditions of selective individuation - and hence the conditions of the possibility of "noble excellence" itself - that had once been realizable within the dynamical setting of the authentic agon. ${ }^{23}$ There is a profound kinship in this instance between Burckhardt's sense of a potential, "higher man" and Nietzsche's familiar overman. Both figures espouse a conspicuous anti-egalitarian, "philosophy of difference." They share a comparable, quasi-dialectical perspective of the world which imagines the rara avis of "excellence" in constant mortal contention with banality - with the "herd." While Nietzsche's particular intellectual disposition inclines him to favor a direct "philosophy of action" (Nietzsche once remarked: "I am not a man, I am dynamite!") and a corresponding belief a "great man" theory of history, Burckhardt on the other hand makes next to no mention in his Greeks of traditionally "great" figures such as Pericles, Alexander, Lycurgus, etc., in anything but a cursory fashion. ${ }^{24}$ Burckhardt is in fact suspicious of the notoriety garnered by such personages of power. For Burckhardt, the dialectical synthesis of Greek higher culture is only made possible within the suitably tumultuous environment of the "agon of the polis" - amidst the natural antagonism of the "free" individual against the homogenizing forces of submission and conformity. Burckhardt nonetheless never loses sight of the indispensability of genuine Gemeinschaft for the production of culture. Nietzsche's recurrent sense of statelessness, of Zarathustrian eremitism, is, by 
contrast, consistent with an out-and-out rejection of community - a rejection, moreover, of definite human historical continuities. The credo of Zarathustra, we may recall, is put pithily: "I teach you the overman."25

These key differences of perspective are reflected, once again, in the respective disparity of Burckhardt's and Nietzsche's iconoclastic receptiveness. Where Burckhardt is, in no uncertain terms, highly critical of the state of modern affairs, he stops well short of advocating the radical - even annihilative - approach per Nietzsche:

Unlike Nietzsche, Burckhardt had no willingness to assume the part of destroyer of all things present, and the aristocratic liberal in him balked at the presumption of Nietzsche's desire to become the legislator of the future...[with Nietzsche a conservative critique gives way to an] all-destroying and ultimately self-destructive position, one that Burckhardt mistrusted, feared and predicted would ascend rather than wane during the approaching twentieth century. ${ }^{26}$

Both figures inform their modern critiques through a shared, overtly historical perspective, and each unquestionably applies the model of antique "high culture" as a paradigm for self-realization, yet Nietzsche makes a case in his later works for the ascendance of an eradicative, post-historical consciousness. Despite this crucial difference, it is important to understand Burckhardt and Nietzsche as sharing a common belief in an historical agon which affirms a sense of the many-sided entelechies of the individual. Their mutual vitalistic interests are bound up in the pervasive confrontation of the self with the forces of certain annihilation, typified by the modern will to homogeneity. In the same way that the joint methodological perspectivism of Burckhardt and Nietzsche bears a likeness with the contemporaneous, representational iconoclasm of Monet, it is likewise possible to 
discern a resemblance to the Fauvism of Matisse in the the shared stress these theorists placed upon the "free" excitation of certain vital energies, particularly in the case when such excitations are directly provoked through an agonal-type struggle.

\section{Problematic Greece: The Agon and a Critique of Modernity}

Burckhardt's central placement of the agon within Greek culture highlights the unconventionality of his Greek reception and points to his underlying, historically-activated critique of modernity. ${ }^{27}$ For Burckhardt, the contest in Greek society indicates an attempt to sublimate the multitude of antagonistic impulses and energies of a collective, pre-Homeric, Ur-consciousness. The agon imposes a transformative structure upon these undifferentiated drives; it entails in this regard, as Richard Sigurdson has noted, a typically Burckhardtian-minded "striving within limits." 28 The Greek ideal of the individual, which parallels Burckhardt's prior conception of the many-sided individual of the Renaissance (a model which will serve as a cornerstone for Nietzsche's overman and great man paradigms), incorporates a sense of the complete man: "the harmonious combination of all qualities with none predominating; if at all possible the Greek desired to be a whole man, and could be one if he devoted himself to public life, gymnastics and noble culture. ${ }^{29}$ In this way the Greek contest connects with the notion of sophrosyne (selfcontrol), a term Burckhardt also applied to Greek art. Burckhardt conceives of freedom as value-laden to the extent that it is mediated through a coherent system of meaning - and in many ways, historical perception provides a framework for such mediation. The groundedness of the agon abounds with certain moral (in a prephilosophical sense) implications, for Burckhardt asserts that the effloresence of the 
Greek contest marks a distinct inception of human-affirmation as a distancing from our pre-cognitive, ahistorical consciousness - a distinction which Nietzsche will later refuse to recognize.

By injecting Greek culture with a certain "active" and elusive identity, with the problematic symbology implied by the notion of self-creation through a simultaneous instance of self-destruction, Burckhardt achieves a significant deviation from German Hellenism and even the terrain of conventional post-Enlightenment thought. With the invocation of the agon, Burckhardt challenges our key presumptions related to the validity of traditional concept-mindedness. If the Greeks, the proverbial forbearer of western civilization, "suffered" from such inner volatility and discord, how does this then bode for us? Furthermore, how does it now stand with modern self-conception? The problematization of the Greeks as multi-layered, as given to counter-rational and even apparently uncognizable configurations, reinvests them as once again fully human and thereby explodes the modern concept of humanity from within. Though Burckhardt's innovative formulation of the agon is in part, of a piece with a larger, Schopenhauerian conceptual lattice-work (here the agon is descended from the will), Burckhardt instead conspicuously celebrates the affirmation of the will qua agon.

The agon was the domain of an internal, mortal struggle externalized and reified in Greek society (through the polis), "a motive power known to no other people...that proved capable of working upon the will and potentialities of every individual." ${ }^{30}$ The Greek contest spurred a continual process of self-confrontation and, by turns, self-affirmation without which, as Nietzsche would later posit, Greece 
and her glories would be inconceivable. ${ }^{31}$ All ages of history must cope with the collective interrogation of the human condition; this much is a basic verity of civilization. The development of these coping processes should work in the direction, according to Burckhardt, of the encouragement of human excellence and of the intensification of the human will-to-live. The elevation of society's responsiveness to the new and multiform varieties of human "situatedness" is absolutely vital, in Burckhardt's reading, to human ontogeny.

Burckhardt's understanding that human development through history comprises the positive, ontogenetic advancement of self-conception, leads him finally to assess what he considers the present-day devaluation of the agon as a signal of the spiritual and moral degeneracy of modernity. The agon, in other words, does not only provide a conceptual inroad into Greek excellence but it equally exposes our considerable present-day deficiencies by comparison. In its most obvious meaning, Burckhardt's treatment of the agon sheds light on his various aristocratic inclinations, something Nietzsche will later seize upon with the development of his own "pathos of difference." The agon favors the advancement of kalokagathia (the unity of nobility). Greek competition encompasses a "blind will," but this will is redirected and articulated anew as socially meaningful in its agonal mode. The agon thus authenticates excellence in a way that is decidedly unstructured and unmediated by commonplace artificiality. Burckhardt recognizes the Greek contest as "excluding practical usefulness" and as serving a non-material and non-utilitarian purpose in ancient society. Whereas in modernity the obsession with "utility," with material gain and petty egoism imposes a "social inhibition" against the genuine contest and 
"hardly permits any competition except in business affairs, and otherwise restricts the individual to the negative aspects of the feeling for honor," in antiquity the agon conversely stems from a "favorable pursuit of honor" and is unimpeded by efforts to assimilate competition to democratic or populist-utilitarian standards.

If we look at the role of competition in our own world we are instantly struck by the chief difference, which is that the Greek agon always had the entire population as its audience and witness...Men of today are far more likely to want to win financial success than rapid recognition of their talents, and they know perfectly well why the success they seek is of a material kind; life requires it. ${ }^{32}$

Buckhardt shares a remarkable consonance with the equally "out-of-time" second century CE Greek antiquarian, Pausanias, who is best remembered for having written the antique "travel guide," Description of Greece. Burckhardt immersed himself in the Description of Greece at the time of his lengthy research for his Greeks and Greek Civilization - when he was, as he put it, sailing in the "real spiritual ocean of the world"; he furthermore cherished his Pausanias as a kind of vade mecum that provided newfound inspiration for his late art historical predilections. ${ }^{32}$ Burckhardt's Cicerone (1855) was a widely popular piece of travel literature in its day, which, in its descriptions of sculpture and architecture from the Italian Renaissance, was suggestive of Pausanias in both its Epimethean tone and with respect to its culturalpedagogical purposes. Like Pausanias, Burckhardt imagined himself in his role as an historian as an intermediary between historical objects of culture and present-day practitioners of culture:

When Pausanias toured Greece in the second century, he became acutely aware that the places of worship and many of the other great monuments of classical antiquity had begun to fall into ruin, and he resolved to save for posterity their last visible vestiges of glory, the 
images of their legendary past, their myths. ${ }^{33}$

Burckhardt's Cicerone abounds, as one similarly finds in Pausanias, with a conscious air of accessibility, of "amateur" wonderment and dilettantish affections. Joseph Mali has observed the subtle resemblance of Burckhardt's acute awareness "of the contingency of all human affairs," in the fragility, even of humanity's seemingly sempiternal glories, to Pausanias' mutual recognition of the whims of fortune that have, as he once observed, rendered even the monuments of the victors at Troy to dust. ${ }^{34}$ It is possible in this regard to recognize the shared tragic aspect of these two figures. Burckhardt and Pausanias are bound together by their mutual sense of vertiginous loss - an awareness that theirs is an age of impending decline for which the relics of history, viz. of culture and art, appear to us as beacons in a dense fog and are thus offer a melancholic reminder of humankind's rare and luminous potentialities. There is likewise an undeniable perception, as seen through the dual lens of these two curators of "Old Europe," of estrangement, of profound disenchantment - not with "the world," as Nietzsche remarks, but rather with this world - this present-day; such was their keenly felt untimeliness.

\section{The Sophists: Reason and Dominant Ideologies}

Burckhardt's fifth century lectures contain an importation discussion relevant to the rise of Greek philosophy and the coeval "democratic shift" in Greek society. The fate of sophism, a traditional nemesis of the logocentric philosophical program of mainstream western philosophy since Plato, has always been shrouded in mystery; it is, moreover part of the fabric of an historia abscondita. ${ }^{17}$ Our very language is coded, pointedly, with a disapproving estimation of the sophistical temperament - 
indeed, "sophistic" is today synonymous with fallacious; to practice sophistry is, accordingly, to disparage human reason, and to denigrate, more extremely, the purported inner harmony of nature herself. Burckhardt's analysis of the heretical tradition of sophism is consonant with his own central "epistemic doubt" and likewise with the unfavorable appraisal of canonized philosophy that he shares with Nietzsche. In one sense, Burckhardt portrays the sophists in a somewhat typically negative way (though such "disapproval" still attests to his basic counter-modern convictions); here he imputes to them the deterioration of the oratorical agon into the falseness of rhetoric:

They [the sophists] placed more emphasis on specialized knowledge and accomplishments for practical application - which could be taught - than on claims to awaken convictions. In this aspect they were wholly indispensable mediators of a kind of training suddenly much in demand, but as yet very little sustained by systematic studies. ${ }^{36}$

While Burckhardt is critical of the utilitarian knowledge professed by the sophists, of their dubious celebrity and popular acclaim, and of the somewhat paradoxical role of sophism in the development of formal logic, he also receives them as offering a salutary and indispensible anti-logocentric perspective for Greek thought. In the opaqueness of the sophists there is certainly a resemblance to the mystery of Heraclitus, and in their belief that reality is a "waking dream," there is something of an aesthetic, even poetical tendency. Burckhardt notes that the philosophical starting point of the sophists, "that there is no such thing as true and generally valid perception, no knowledge, only imagining, is in itself tenable"; and that they "probably deserve a lot of credit as pioneers of the skeptical attitude to the proof of perception.",37 
The heritage of Platonism, up through orthodox Kantianism, is committed to the authenticity of modes of representation (linguistic or otherwise). Platonism asserts, for instance, that there is a rational, semantic-driven archetype of "Socrates" that endures even in the absence of its real-world counterpart; it is in this sense that the word-signifier is an emblem of the true, trans-phenomenal Socrates; the word, that is, maps perfectly onto a rationally-construed metaphysical object - or in modern parlance, onto the Kantian the thing-in-itself.

The sophists threatened the semantic-ontological worldview of Platonism because they doubted the ability of language to represent reality authentically. The sophistical argument accordingly partakes of a form of "mental gymnastics and logical traps" which serve to indicate the tenuousness of language - and of reason itself. ${ }^{38}$ Sophism repudiated the Parmenidean-Platonic assurance in the constant meaning of words by calling attention to linguistic polysemy and to the underlying relativity of truth-value assertions (insofar as "man is the measure of all things").

Sophism thus points to the structural incompleteness of language. Aesthetics and particularly poetry have traditionally, in the modern German intellectual tradition, provided a means to escape these limitations by embracing more fluid standards for conceptual orthodoxy; and indeed, we have seen with the heterodox Kantian thinkers, including Burckhardt, a coincident primacy afforded to aesthetics. There is, in Burckhardt's dissenting historiographical tendencies, a desire to plumb the depths of conventional historical receptions of Greece in order to expose the failings of empirical logic-deductive hypotheses and to thereby access the recesses of the Greek psyche. The attempt of sophism to undermine what is deemed, in the logocentric 
tradition a priori truth - whether it be in relation, for example, to the proposition that reality is fundamentally Euclidean (an issue of considerable worth in western, moreover, German intellectual history at the time that Burckhardt was giving his Greek lectures), or perhaps more incisively, with respect to longstanding ethical presumptions - was common, analogously, to the Burckhardtian project and also that of Nietzsche's genealogical efforts in particular. ${ }^{39}$ The sophists maintained a philosophical posture that is less restricted by a set of indurate, ethical-ideological presumptions:

The sophists were prepared to follow an argument wherever it might lead them. Often it lead them to skepticism...Plato [contrarily] is always concerned to advocate views that will make people what he thinks virtuous; he is hardly ever intellectually honest, because he allows himself to judge doctrines by their social consequences. Even about this, he is not honest; he pretends to follow the argument and to be judging by purely theoretical standards when in fact he is twisting the discussion so as to lead to a virtuous result. ${ }^{40}$

Both Burckhardt and Nietzsche abandon the snare of a priori presumption; they do not reaffirm presuppositions which exalt the virtues of reason or the artlessness of God. ${ }^{41}$ Instead, beginning from a generally skeptical standpoint, both figures pursue historical inquiry in a discursive or dialectical manner as a means to rebut the "false consciousness" of dominant ideology. ${ }^{42}$ Indeed, this is in many ways the initiation point of their respective Greek receptions. ${ }^{43}$

Burckhardt's and Nietzsche's interpretation of sophism correlates with their mutual interest in the problem of power. Sophism, "this invaluable movement amidst the moral and ideal swindle which [was] just breaking out on all sides, that of the Socratic schools," has suffered the fate of a concerted, historically-affirmed 
marginalization that began in the instance of its early confrontation with Plato. ${ }^{44}$

Burckhardt observes:

It seems to us that the sophists have been taken altogether too tragically. People have paid too much attention to the voice of the Platonic Socrates...Because of their doctrine that there are two sides to any question, they are supposed to have preached ethical indifferentism and thus hastened the process of decline. But there is nothing inherently objectionable about the idea that opposite opinions on any topic may be equally well defended and made to seem plausible by good arguments: it simply articulates a fact and makes it a matter for the student's conscience that he defend only what truly seems right to him. On the matter of the application of this idea to law and morality, we would really have to have better sources than Plato, who was in competition with the Sophists. ${ }^{45}$

The historical "fate of sophism" bespeaks a greater, historical problem of power in which various forces of domination - both past and present - work to guard the "production" of truth.

Burckhardt's and Nietzsche's historical ruminations reveal a willingness, largely absent in nineteenth century historiography, to not only "disturb what was previously considered immobile" (Foucault) - but also to implicitly interrogate the systemic manner in which truth is governed by historical perception. "Truth is linked," Foucault says, "in a circular relation with systems of power which produce and sustain it [truth], and to effects of power which it induces and extend it."46 Burckhardt and Nietzsche adopt a common understanding acquired via Schopenhauer, of the primacy of the world-will and of the innate asperity of life. This outlooks inspires in both theorists a demythologized-mythological perception of modernity, and history by extension, which includes a prominent assessment of the menace of dominant ideology. Burckhardt and Nietzsche were both driven in part by 
a sense of intellectual pessimism and by a persistent Machiavellian conception of politics and of history. ${ }^{47}$ Each thinker's readiness to extirpate history of an objective purpose allowed him to better conceptualize history as an endlessly repeated struggle for power, viz. a "will to power" that consists in a "play of dominations.", "What makes power hold good, what makes it accepted, is simply the fact that it doesn't only weigh on us as a force that says no, but that it traverses and produces things, it induces pleasure, forms knowledge, produces discourse."49 Burckhardt's pointed reference to the sophists - a group that is unanimously rebuked in mainstream philosophical discourses, illustrates his novel understanding of the structural embeddedness of power, a concept that had a subsequently profound influence on Nietzsche. 


\section{The Problem of Power: Burckhardt Contra Nietzsche}

\section{A. Nietzsche: Anti-Historian?}

Richard Sigurdson has suggested that Nietzsche's understanding of power his encompassing "vision for the future" - emerges from an appropriation of Burckhardt's historical studies. ${ }^{1}$ Nietzsche's prominent glorification of Borgia, Caesar, Napoleon, and other "great men," resemble, in part, Burckhardt's ruminations about power from his lectures Reflections on History, which Nietzsche attended. Nietzsche's belief an historically-affirmed "play of dominations" - a perspective that is first adumbrated in Burckhardt's study of the Renaissance and further developed in his analysis of the Greek polis, inspires his doctrine of the will to power. Nietzsche parts

with Burckhardt on the problem of power when as it applies to the full implications of his critique of modernity. Nietzsche believes that similia similibus curantur (like things are cured by like things) so that only power of a higher, transvaluative type, derived from genius can overcome the contemptible ideals that today hold humanity in perpetual thrall. ${ }^{2}$ Burckhardt is conversely reluctant to "radicalize" his views on power and to turn them into what Nietzsche calls a "philosophy of action." His reluctance was based in grave, and seemingly well-placed, misgivings about attempts to use power as a practical end in itself. There is an historically topical, catastrophic attitude present in Nietzsche that marks a great departure from Burckhardt. ${ }^{3}$ Where Nietzsche delights in the idea of the "future man" who fosters an attitude of radical historical reinvention to the point even of the willed destruction of the past, Burckhardt by contrast abstains from pursuing such extreme designs. Burckhardt's 
commitment to the moral imperative of the continuity of culture precludes him from such any sense of ahistoricality. ${ }^{4}$

Much of Burckhardt's unwillingness to embrace the viability of the benefits of power - in contrast with Nietzsche's readiness to walk this path - reflect the disparity of their roles as historians. Nietzsche's formative worldview, including his reception of Ancient Greece and Renaissance Italy, the age of revolution, the "massification" of modern society and the emergence of amoral, historical great men, is culled from close readings of Burckhardt's own ideas. ${ }^{5}$ In a comparative study of Nietzsche and Burckhardt, Alfred von Martin contrasts Burckhardt's passionate opposition to the increase of state power and military technology with Nietzsche's abstract speculations about immoralism, the will to power, and the coming Übermensch; where Burckhardt distrusts abstract thought, Nietzsche's bent is often speculative and comparatively callow. ${ }^{6}$ Nietzsche's prominent futurism was, for Burckhardt, a signal of the lowly, ahistorical disposition of modernity. Karl Löwith contends that Nietzsche saw history as justified only within the service of the powerful forces of life, while Burckhardt valued historical reflection as a means of gaining knowledge about the misery and blindness of the will and therefore of achieving the only possible redemption to the spirit of the modern world. ${ }^{7}$

In my reinterpretation of Burckhardt, I wish to challenge the hypothesis that Nietzsche overcame the "lesser," antiquarian Burckhardt - and that in doing so, he laid to rest the moribund body of pre-modernity. We moderns wish to see Nietzsche in ourselves - and certainly torchbearers like Walter Kaufmann have inclined us, in part, to leave the oft-shaded groves of Nietzschean thought in search of its warmer, 
sunlit vales. Nietzsche is an ontogenetic stage in the birth of the modern species, we might say; he is an overture. But a natural question then arises: to what (and to whom) is Nietzsche an overture?

In the century since Nietzsche's death we have witnessed attempts to actualize a will to power with immensely ruinous ends. ${ }^{8}$ Curiously, despite the openly incendiary potential of his ideas, Nietzsche is traditionally, in post-Kaufmann reception, regarded as more intellectually palatable and more central to the inception of a "positive" modernity than Burckhardt. As I see it, two principal misconceptions have led to this state of affairs. First, there is the matter of the tendency to perceive Nietzsche as conquering the elder, patriarch-like Burckhardt (Nietzsche in some respects supported this characterization). Burckhardt is a comparatively obscure and even unsettling figure to most modern readers by virtue of his "old world" austerity and his stark anti-bourgeois and anti-democratic sentiments. Where today Nietzsche is almost unanimously hailed as a harbinger of the modern shift, (and in this way there exists a propensity to see "Nietzsche" as an historical inevitability) Burckhardt is by contrast often confined to a kind of Tartaros of counter-modernity, of outmodedness and intellectual obsolescence. The second post-Kaufmann related narrowing of Nietzschean philosophy has come in the manner of the common bowdlerization of his ideas. Popular reception of Nietzsche in the second half of the twentieth century, particularly in English-speaking venues, has tended to present a castrato-type, of Nietzschean thought, to borrow his own phrase. It is accordingly common to encounter today a strangely pluralistic Nietzsche, a simple truth Nietzsche devoid of much of his original ideologically seditious content - where existentialism, 
shallow psychologism, hyper-subjectivity and a pervasive valuelessness, among other "conceptual monsters," rear their heads. ${ }^{9}$ Nietzsche is commonly presented in this way as an innocuous antidote to modernity's genuine maladies - to the conditions of subjugation enforced by Enlightenment ideology, the Faustian pursuit of knowledge and the relentless productions of capital. ${ }^{10}$ In this tradition, Nietzsche acts as a rejoinder to the profound "disenchantment of the world," but only in parody; he is, we might say, another Socrates.

These post-Kaufmann interpretative postures have significantly hindered Burckhardt reception. Together, the inclination to identify the modern era in an aseptic way - to dismiss the calamities of our age called forth by the "totalitarianism" of the liberal Enlightenment - and to furthermore expurgate Nietzschean philosophy of much of its inflammatory content, all point to the overarching attempt of modernity to sublimate various counter-normative ideas. In this fashion, predominant Enlightenment-rationalist ideology co-opts Nietzsche's potentially antagonistic aspect: abject power reinvents a Nietzschean, superlative power; the "higher man" of today is built with the mortar of progress - a "merely modern idea, that is, a false idea." 11 On the surface, the disparity between Nietzsche's and Burckhardt's considerations of the "problem of power" certainly affected the degree to which the ideas of each figure could be made to harmonize with the prevalent modern "regime." For Burckhardt, power is a force "evil in itself" that operates according to the mandates of its own, unbridled will; it is a counter-force to culture and the redeeming essence of civilization. ${ }^{12}$ Nietzsche conversely understands power qua the will to power as a conduit to superior culture. While Nietzsche's doctrine of power is 
notoriously amenable to a variety of diverse interpretations, we cannot however ignore the Nietzschean-like legacy of this past century (whether such a legacy is authentic to the spirit of Nietzsche is immaterial here) consisting in the advancement of new, nakedly brazen manifestations of power. Nietzschean philosophy incites us at last to "unlearn" history: "history must itself dissolve the problem of history, knowledge must turn its sting against itself."13 In this way, Nietzsche understands the requisiteness of power in the production of history and for life. Nietzsche encourages the dissolution of erstwhile history in favor of an elevated, ahistorical consciousness. His ruminations on power, particularly in the case of his conclusive will to power principle, today resonate ominously in their revelation of an ultimate determination to embrace the unfettered exercise of power.

\section{B. The Polis and the Modern Nation-State}

Burckhardt's historical-mindedness, his penchant for perceiving politics and history in a non-idealized and equally a non-philosophical fashion, as well his soberly existential conception of humanity, prevented him from sharing Nietzsche's final acclamation of power. Burckhardt's astuteness on matters of politics and the motley historical uses and abuses of power (with many of them occurring - and this is, in part, one of Burckhardt's great achievements as an iconoclastic historian - during supposed "golden eras" in history), as well as his enduring critique of modernity and different evocations of historical heterodoxy, are all well illustrated in his provocative analysis of the Greek polis. ${ }^{14}$ With his unique reception of the polis, Burckhardt aims to both undermine the narrow German philhellenist glorification of the Greek citystate as a utopian, lost paradise and to draw certain, foreboding parallels between the 
polis (specifically the degenerate polis) and the modern nation-state.

While Burckhardt's examination of the polis is typically nuanced and variously hued with ironic and even deliberately contradictory elements, his reception of the Greek city-state is predominantly negative: "in the whole of history...there is hardly another such accumulation of bitter grief as in the Greek polis." 15 Despite a confidence granted that the polis was a "creation unique in the history of the world,"16 that it expressed and directed a common will of the "most extraordinary vigor and capability," the polis also necessitated, as Burckhardt makes evident, the eradication of the individual through one's total enslavement to the state-ideal: the "Eins und Alles" of the state. The polis was completely and mercilessly inescapable for the Greek: "Man in the polis is a citizen, never an individual." ${ }^{17}$ Lionel Gossman has, through Burckhardt, envisaged something of a twofold attack issued against the individual Greek through the polis that is loaded with potential present-day analogies. Externally the polis was engaged in open and interminable warfare with other poleis in the service of a veritable "balance of power," a cause for which the individual Greek was deemed expendable; while internally, the polis imposed a life sentence of the total and unwavering dedication of mind and spirit. Burckhardt substantiates his pessimistic conception of the Greek polis with evidence gathered from Greek myth a sort of "golden road" to the Greek psyche. Greek myth is rife with indications of an entrenched anxiety pertaining to the "traumatic birth" of the polis, of which the stories of Cadmus' foundation of Thebes and Danaus' foundation of Argos, to name but two such instances, are canonical examples. The Greek polis in the Burckhardt reading discloses the self-alienating imposition of civilization and the genuine 
discontendedness that attends the renunciation of individuality. In the imagination of modernity, the destructive and oppressive reality of the polis devastates our own relativized conception of the "free and happy" Greek and likewise of the free and happy modern. For Burckhardt the state is a "work of art" of a Machiavellian sort, that is, a nefarious sort, and yet the state is indeed, in part, a necessary evil, for the total extirpation of the polis in Greek society would certainly obviate the celebrated higher achievements of Greece. In this way, Burckhardt's treatment of the polis acts as an allegory of power tempered with earnest, historical reflection in a way that propels his analysis beyond the comparative naiveté of Nietzsche. It is finally the Greek dawn of reason that brings an end to the spiritually leavening function of the polis - and here the decline of the polis, as Burckhardt envisions it, offers a propaedeutic for criticism of the modern nation-state.

Burckhardt thus draws a correspondence between the decline of the Greek polis in its democratic and philosophic turn with the emergence of the postrevolutionary modern nation-state.

Democracy aggravated the hardships that human life itself invariably brings by undermining the ideals that had stimulated men to make enormous efforts, despite hardship, for the sake of the goals they believed reached beyond themselves. As the old unity in the polis of state, culture and religion disintegrated and as society fell under the sway of a greedy and resentful populace and the demagogues expert manipulating its passions, gifted and noble-minded individuals withdrew in ever larger numbers from all participation in public life. ${ }^{18}$

The decline of the polis marks the emergence of the possibility of an Alcibiades in Greek society - an historical precursor of the (modern) mass, uprooted individual, who is not only alienated from a genuine holistic conception of humanity and of 
community but one who furthermore actively revolts against attempts to cordon individuality within definite limits.

The permanent mood of the Athenians was as if something has been stolen from them. We are dealing here with a demos that has in part truly been betrayed and robbed by those in public office and in part been kept in a state of permanent angry distrust of the state authorities and that has become insatiably greedy for pleasures and handouts as a result. $^{19}$

\section{As Gossman observes:}

The historian's jaundiced view of development that threatened the 'culture of Old Europe' - the growth of state power and the rise of fiercely competitive nationalist states, the spread of democracy and populism...the industrialization and rationalization of all areas of human activity, which he saw as the triumph of philosophy and of the rationalist, enlightened project to achieve domination of nature - can usually be sensed in his judgments of the ancient polis. ${ }^{20}$

Burckhardt's critique of modernity through his engagement with the Greek polis is nevertheless more profound and forward-leaning than Gossman advances. For all the theoretical dissent encompassed in the ideas, for instance, of an historian such as Marx (certainly we may choose other examples), the conditions of historical canonization are never open to question; the present is therefore fixed in a static, rationally-ordered teleology that imagines the past to have been written once and for all. Burckhardt is, in my view, by contrast, amenable to a more dynamical consideration of the process of historical canonization. He imagines the present-day governed by sundry modes of domination (or power relations) which have arisen out of the heritage of reason. Burckhardt understands well the centrality of historical studies, through the cultivation of an historical-self, in the evolution of the modern disciplinary matrix. His historical project offers the tantalizing view that not only is 
mainstream historical perception nominally "mistaken" but that history - namely historical perception - has led in some sense to an erroneous and ill-fated present; the past is thus something we retrieve and also something that we must overcome.

\section{Pessimism Reassessed; Burckhardt Reassessed}

Burckhardt's conception of Greek pessimism is one of the most intriguing and deeply misunderstood aspects of his entire Greek reception. His understanding of the “dark" Greek consciousness provides a keystone for the edifice of Burckhardt's general historiography, particularly with respect to his multi-sided critique of modernity. The designation of "pessimism," a term Burckhardt himself employs, is unfortunately - and this is Burckhardt's incendiary point - replete with a philosophical unseemliness which has consequently hindered not only modern conceptions of Greece but also our present-day understanding of Burckhardt. In its starkly anti-teleological aspect and through its implicit renunciation of a general, optimistic will, philosophical pessimism is at variance with the underlying canons of mainstream post-Enlightenment thought. Pessimism, to take it even further, deprives us of the various (psychological) consolations of philosophy, of the analgesic benefits

of reason and the categorical assurance of our cosmic significance. Seen in this way, pessimism is our great nemesis, an incorrigibly life-denying force.

Burckhardt's pessimistic turn exemplifies his departure from mainstream German Hellenism. For Burckhardt, Greek pessimism provides an inroad to a more internally dissonant - and thus a more conceptually challenging - historical tableau.

Since the flowering of German humanism in the eighteenth century, the position of the ancient Greek [disposition] was thought to have been settled. The glory of their heroism in war and of their political 
achievements, their art and poetry, the beauty of their country and climate, all caused them to be considered fortunate, and Schiller's poem 'The God's of Greece' conveys all these assumptions in an image which still retains its magic. At the very least, those who lived in the age of Pericles were believed to have enjoyed rapturous happiness from one year's end to the next. This must be one of the most tremendous historical falsifications that have ever occurred, and the more innocent and single-minded its proponents, the more irresistible it was. $^{21}$

Such falsifications, i.e. sublimations, of Greek "cheerfulness," if we take the analysis to a more advanced stage, existed, quite naturally, in antique conceptualizations (or self-conceptualizations) themselves. Burckhardt explicitly aligns himself with a broadly incisive and consciously unstudied "Herodotean" posture - "Herotodus [who teaches us] the wretchedness of life" and who, according to Burckhardt, served to illuminate the adumbral, inner Greek to Greece at large. ${ }^{22}$ Burckhardt's foray into philosophical pessimism is not a mere derivative appropriation of Schopenhauerianinspired psychologism. Though the historian's pessimistic inclinations lead him along a post-Kantian path paved, in large part, by the philosophical "heresy" of Schopenhauer, Burckhardt's pessimistic turn is conversely indicative of an ultimate, post-Schopenhauerian sensibility - of even a "Nietzschean" sensibility. Through his exploration of Greek pessimism, Burckhardt intimates a move beyond the horizon of the restrictive linguistic-conceptual categories and beyond also the axiomatization of self-conception. His modern Zeitdiagnose acknowledges, at its core, the saturation of such models. Burckhardt would move us beyond our innate (or is it conditioned?) revulsion to pessimism in an attempt to comprehend a fuller sense of the conditions of possibility pertaining to the human situation. Pessimism is not an incontrovertibly life-denying impulse. It is not borne out of a nihilistic drive toward self-immolation 
but is instead consonant, in a Burckhardtian reading, with a postmodern affirmation of life through the problematization of the self and of man more generally.

The spiritual decline of the earth is so far advanced that the nations are in danger of losing the last bit of spiritual energy that makes it possible to see the decline, and to appraise it as such. This simple observation has nothing to do with cultural pessimism, and of course it has nothing to do with any sort of optimism either; for the darkening of the world, the flight of the gods, the destruction of the earth, the transformation of men into a mass, the hatred and suspicion of everything free and creative have assumed such proportions throughout the earth that such childish categories as pessimism and optimism have long since become absurd. ${ }^{23}$

The effectiveness of Burckhardt's discussion of Greek pessimism lies partly in the novelty of its scope, in its frankness and in the intimacy of its voice; and although the general tenor of Burckhardt's Greeks is vastly different from that of contemporary histories (and even most present-day histories, for that matter), Burckhardt's account of Greek pessimism nonetheless exudes the simultaneous piquancy of alienation and familiarity. Pessimism is here a terrestrial symbology, for it encodes history with a distinctly human pathos. Burckhardt's train of argument in his investigation of Greek pessimism involves a methodical overturning of our most basic and deeply entrenched presumptions pertaining to the Greeks. His Greek lectures compel us to submit the body of the Greek value-system - as well as our own system of values - to a scrupulous vivisection.

Burckhardt's deconstruction of Greece violates the sacrosanctity of modernity's most steadfast and pervasive illusions or self-delusions, relating to, among other ideas, the Greek disposition, the role of heroes, and historical teleology at large. Burckhardt begins with an effort to explode the fundamental misconception 
of Greek "happiness." While the Greeks display on the one hand a multiplicity of optimism about life and human potentiality - they could not have otherwise produced the august works of art and of human intellectation with which the idea of Greek culture has today become synonymous - Burckhardt nevertheless contends that the Greeks were equally possessed by an intense and multiform "will to seek out darkness." For every Anaxagoras who posits "it is better to be born than not to be born," there is an analogous and contrarian voice in Greek society - a Sophocles - as Burckhardt reminds us, who declares, solemnly: "not to be born is best, when all is reckoned." "Taxing oneself to the utmost, struggling to reach the very limits of one's capacity, was not incompatible among the early Greeks with pessimism. On the contrary, it was the heroic response of a lively and gifted people - as, mutatis mutandis, it might be seen to have been Burckhardt's own response to the century of Blood and Iron." ${ }^{24}$ Burckhardt's analysis here is built in large part upon the protoNietzschean principle of a Greek synthesis. The Greeks were not wholly or wretchedly pessimistic by Burckhardt's reading, but instead they "suffered" from a "fuller awareness [than other peoples]" - theirs were the "sufferings of rational man...the Greeks had become individuals earlier than others, and experienced the glory as well as the pain of this condition." The Greeks unearthed - in part, through the apparatus of the polis - a Promethean capacity in themselves and in man, more generally, which was nonetheless laden with an unmistakable sense of foreboding and dread. We are reminded, to this end, that according to common Greek myth, two vessels of destiny stand at the threshold of the house of Zeus and that no one receives his share from the good vessel alone; as Pindar recounts: "for each good thing the 
gods bestow two evils on mortals." ${ }^{25}$ Burckhardt asserts that Greek identity is inseparable from this synthesis of antitheses. The continual oscillation of opposing forces, of, in particular, the opposition of human conditionality and the immeasurableness of ideality, are what ground, at last, the tragic essence of the Greeks.

\section{Pessimism and Zeitdiagnose; Rebirth of Tragedy}

Pessimism affords Burckhardt an opportunity to reexamine the Greek conception of heroes and to interrogate the follies of modernity. Burckhardt's purpose here is apparently to devalue the notion of a hero in its modern context. For Burckhardt, the Greeks regard Achilles not as the savior of the Mycenaeans and the "doer of great deeds" but rather as a figure who was, because of his impetuousness, a liability for the Greek cause. He is remorselessly violent and yet for all his warrior bravado he is burdened by a deep-seated fear of the fate that war has assigned him. The source of his raison d'être is also that of his demise. Daedalus, myth's first artist, is a "terrifying character, and the oldest example of a legend common to all nations that of a master who murders his apprentice for envy of his talent." ${ }^{26}$ Herakles, known for his labors, was seen in popular belief as a persistent symbol of "menial drudgery" and of the inescapability of banausos. In their attempts to "return home," Odysseus and Ajax expose the hollow "vanity of a great victorious campaign." Their returns are ironically marked by the agony of self-confrontation; Ajax's "return" is of course merely figurative. A hero, in short, in the Burckhardtian reading of Greece, is not an object of veneration. Rather, a hero should serve as a lasting object of pity, as a source of psychological dissonance. The various "defects" evinced by such 
personages prompt us, with Burckhardt's urging, both to reconsider the way in which remembrances are codified historiographically and to thereby interrogate our own values, particularly those pertaining to modern criteria for "greatness." In addition to the basic Greek inversion of the hero-ethos which modernity has consciously derealized (entfremdet), Burckhardt examines the recurrent theme of the "early death" of the hero. Looking at the common, precipitous deaths of the character of Adonis, Achilles, Hippolytus and Androgeus, Burckhardt emphasizes the fragility of life vis$\grave{a}$-vis the timelessness of the gods and of our fatedness. Much in the same way that the aesthetic sublime exerts of a double-effect upon human perception, the recognition of human fragility in the death of the hero (and by extension, the fragility of civilization) frames human situatedness as incurably fleeting and as closed forever within the Möbius strip of conditionality. However, as Burckhardt makes clear, the identification of human fragility also proves to unpack existentiality as a source of incomparable enrichment. Even the Greek gods, Burckhardt recalls, envy our every minute and transitory pleasure for the very reason that such pleasures are transitory and therefore incomprehensible to ahistorical consciousness.

Burckhardt's pessimistic ventures, particularly in the case of his ruminations on the Greek notion of human fatededness, signify the drift of the historian's antiteleological perspective. Human fatededness, we learn, was for the Greeks a source of unremitting dread; each of the Greek heroes was haunted by his predetermined destiny, entire cities (Troy, Thebes, etc.) were subject to the indubitable and unsympathetic ordinances of fate, and the gods too were basically powerless to oppose (and to understand) the supreme world-will. In recounting Greek attempts to 
come to terms with human agency - and really the examination of fatededness is such a project - Burckhardt underlines, ironically, the case against any form of comprehensible determinism (here: knowable historical determinism). This stance should be viewed as theoretically hostile to the various modes of historical teleology which serve as an indirect form of state-worship, such as those instanced by Hegel, Ranke, Fichte, etc. ${ }^{27}$ While Burckhardt offers copious examples in his lectures of Greek admissions to the unconquerable nature of fate - Aristotle has, for one, proposed that "man is the plaything of fate" - the thrust of Burckhardt's argument is that the Greeks nonetheless understood fate as fundamentally incommensurable and beyond human understanding. Terrible Scylla, in many ways a kind of corporeal manifestation of individual destiny, chooses, in this way, "blameless victims." Odysseus and his men know where Scylla lurks, and of her indomitable presence, but they do not know whom she, in her fickleness, will choose as her next hapless victim and when she will choose them. In light of the core unintelligibility of such metanarratives (and indeed we should consider a kind of global, fate-narrative in this vein) the Greek perspective, in Burckhardt's reading, reinvests human agency with a newfound purpose. Because our destinies are forever hidden from us in the murk of the present - it is, after all, only in retrospect that we begin to comprehend objective meaning and the place of causal relations in our own lives - human agency may be understood as inversely purposeful. If history is only intelligible as a sort of grand, composite recollection, then human actions - as they unfold - are the engine of that process. This reinvigoration of human agency is something of an aesthetic interlude in Burckhardt's analysis. The affirmation of the individual will professes the degree to 
which human creativity actively shapes the world and it equally underscores the importance of human agency in the capacity of the historian's essential "poetic" function.

The full resonance of Burckhardt's pessimistic treatment of the Greeks is finally captured in the author's full-fledged effort to retrieve the historical question of tragedy. As both Richard Armstrong and Dennis Schmidt have maintained in related studies, the intellectual culture of the nineteenth century German-speaking world was inundated with a two-sided crisis which encompassed the perceived "ends" of both philosophy and history.

It is no accident then that at the very moment the question of the end of philosophy came to prominence the topic of tragedy ... as a way of asking about ends, destiny and history - comes forward as a sort of model for asking and answering the questions of such times. What becomes most visible in this coincidence is the link that is drawn between the notions of tragedy and history: an image and conception of tragedy is forged - inevitably with reference to Greek tragedy - in order to illuminate and render intelligible a uniquely contemporary historical situation. ${ }^{28}$

Burckhardt was certainly not the first German-speaking theorist to bring the Greek tragic sentiment within the fold of historical studies (Hegel for instance attempted a similar project). However, the amplitude of his analysis, through his various heterodox and pessimistic inclinations, stretches well beyond those of his predecessors and contemporaries. With Burckhardt, the tragic emplotment of history bears a conspicuously dissonant aspect - a genuinely post-Nietzschean aspect. History becomes, for Burckhardt, gravid with a transformative potential culminating in a peculiarly ethical attitude. Tragedies summon us at once to an "experience which is greater than us and yet to which we belong. ${ }^{29}$ Tragedy does not teach us to 
cognize but to feel - to feel then not as Greeks or moderns, but as humans. Tragedy is thus the quintessential "disclosure of Being" realized through the formal problematization of man. Burckhardt's attempted retrieval of tragedy through the selfdiscovery of historical contemplation is an attempt moreover, to retrieve an ethics responsive to what Heidegger will later call our present-day "loss of Being"; it is, in this way, an effort to inaugurate a rebirth of tragedy. Burckhardt's Greece is an entryway to an ethics that viably contends with the prevailing crisis of modernity. What is finally at stake at this juncture is the opening of a futurea counter-modernity: "one different in a very real sense from that which we can conceive on the grounds and framework of the present" - a future activated by our poetic engagement with history. 


\section{Notes: Chapter I}

1. Franz Gerlach was a teacher of both Burckhardt and the well-known, fellow Basel historian, J.J. Bachofen. The quotation is cited in Lionel Gossman's Basel in the Age of Burckhardt.

2. "Postmodernism was started by Jacob Burckhardt when he transformed classical German historicism into its culture-critical form." Jorn Rusen, "Jacob Burckhardt: Political Standpoint and Historical Insight on the Border of PostModernism," History and Theory. 24 (1985): p. 246.

3. My intention is to offer a modest contribution to the mandate outlined in Meinecke's work from 1948, Ranke and Burckhardt, for a genuine reappraisal of Burckhardt. Friedrich Meinecke, Letters and Documents: 1910-1977 (Boston: Brill Academic Publishers, 2010).

4. Though a good portion of Burckhardt scholarship does characterize Burckhardt as exemplifying a legitimate opposition to Nietzschean thought, such an interpretive schematic - when present - tends to predictably cast Burckhardt as conservative and outmoded, in contrast to Nietzsche's (more passable) iconoclasm.

5. Lionel Gossman, Basel in the Age of Burckhardt (Chicago: University of Chicago Press, 2002), p. 297.

6. "The implication that Burckhardt, unlike Nietzsche, has no relevance in an analysis of the problems of the modern world impedes our full understanding of his political thinking," Richard Sigurdson, Jacob Burckhardt's Social and Political Thought (Toronto: University of Toronto Press, 2004), p. 200.

7. See R. Kevin Hill, Nietzsche's Critiques: The Kantian Foundations of His Thought (Oxford: Oxford University Press, 2005).

8. "The vast literature on [Burckhardt]...often passes over the theoretical implications of his social and political work...[his] thought is often regarded as an escape from modernity into the realm of apolitical historical contemplation; Burckhardt's political ideas thus lose any relevance to the struggles of the modern world in which he lived and taught." Sigurdson, Jacob Burckhardt's Social and Political Thought, p. 4.

9. The following excerpt comes from Burckhardt's analysis of democracy realized through a reading of Plato's Republic. "Further on comes the portrait of democracy, imagine in a future stage, when the poor have killed or driven out all the others, and shared out administrative posts among themselves. Freedom rules and there is no restraint on speech or action. All kinds of people have come to the top, and political offices are to be had for the choosing as if on a Markey stall. Everyone evades 
obligations and regulations as much as possible; crime arouses sympathy, so that those condemned to death or exile remain free and go about in public; education is neglected; a man is honored merely for saying he loves the people. The frivolity of government is paralleled by that of the democratic citizen, who is as wild and capricious as the State; he lives for the desire of the money, one day drunk and enjoying flute music, sober the next, now at the gymnasium, then idle and apathetic, sometimes philosophizing, but spending most of his time in political discussion, jumping up and saying or deciding on the first thing that comes into his head...His life has no order, no inner necessity, and yet he calls it pleasant, respectable, happy." Jacob Burckhardt, The Greeks and Greek Civilization (New York: St. Martin's Press, 1998), p. 279.

10. Sigurdson, Jacob Burckhardt's Social and Political Thought, p. 223.

11. See Isaiah Berlin, "The Counter-Enlightenment," The Proper Study of Mankind: An Anthology of Essays, (New York: Farrar, Straus and Giroux, 2000).

12. Burckhardt in an 1874 letter to Nietzsche: "As a teacher and professor I can maintain that I have never taught history for the sake of what goes under the highfalutin' name of 'world history,' but essentially as a propaedeutic study: my task has been to put people in possession of the scaffolding which is indispensable if their future studies of whatever kind were not to be aimless," Jacob Burckhardt, The Letters of Jacob Burckhardt (Indianaplis: Liberty Fund, 2001), p. 136.

13. See Paul Guyer, Kant (London: Routledge, 2006) and Julian Young, Schopenhauer (New York: Routledge, 2005).

14. Young, Schopenhauer, p. 51.

15. Arthur Schopenhauer, The World as Will and Representation (New York: Dover, 1969), 2:185.

16. Young, Schopenhauer, p. 96.

17. Young, Schopenhauer, p. 97.

18. Young, Schopenhauer, p. 99.

19. Schopenhauer, 1:179.

20. Walter Kaufmann's text, Nietzsche: Philosopher, Psychologist, Antichrist (Princeton: Princeton University Press, 1974), is one such example of this tendency.

21. Jacob Burckhardt, The Letters of Jacob Burckhardt, trans. Alexander Dru. Indianaplis: Liberty Fund, 2001), p. 247. 
22. Friedrich Nietzsche, Selected Letters of Friedrich Nietzsche (Indianapolis: Hackett, 1996), p. 94.

23. Nietzsche writes in Beyond Good and Evil, a passage alleged as a direct address to Burckhardt: 'There are 'scholarly men' who make use of scholarship because it gives them a classically serene façade, and because scholarship suggests that the man is superficial: -- they wish that people should arrive at a wrong conclusion about them." Friedrich Nietzsche, Beyond Good and Evil (New York: Vintage, 1966), p. 137.

24. Friedrich Nietzsche, Selected Letters of Friedrich Nietzsche, p. 255.

25. See Richard Sigurdson, Jacob Burckhardt's Social and Political Thought, 


\section{Notes: Chapter II}

1. Gossman provides a notable exception to the understatement of the influence of Basel for Burckhardt.

2. See H.R. Trevor-Roper's introduction to Burckhardt's On History and Historians.

3. See in particular Nietzsche's Basel lectures of 1869 and 1872, in Volume Six of The Complete Works of F.N. (New York: Macmillan Company, 1924), edited by Oscar Levy.

4. Nietzsche, Selected Letters of Friedrich Nietzsche, p. 346.

5. Gossman, p. 103.

6. Sigurdson, Jacob Burckhardt's Social and Political Thought, chapter 1.

7. Gossman, "The Boundaries of the City: A Nineteenth Century Essay on 'The Limits of Historical Knowledge," History and Theory 25(1986): p. 36.

8. See John Hinde, Jacob Burckhardt and the Crisis of Modernity (Montreal: McGill-Queen's University Press, 2000), p. 198.

9. Gossman, Basel, p. 478.

10. Gossman, Basel, chapter 4.

11. See Fritz Stern, The Politics of Cultural Despair: A Study in the Rise of the Germanic Ideology (Berkeley: University of California Press, 1974), for a thorough treatment of Paul de Lagarde.

12. Rusen draws a direct parallel between the ideas of Burckhardt and Weber. See Max Weber, "The Protestant Sects and the Spirit of Capitalism," From Max Weber: Essays in Sociology. Trans. H. H. Gerth and C. Mills (New York: Oxford Press, 1958).

13. H.R. Trevor-Roper has advocated a similar position on the importance of Burckhardt's lectures on revolution. See in particular his introduction to Burckhardt's 
On History and Historians: "The Age of Revolution."

14. "The most compelling nineteenth century analysis of the relation between forms of historicism, that of Nietzsche, presents [a new perspective.] In On the Use and Abuse of History for Life he depicts subjective historicism as being of benefit to modern life if not depended on excessively, while it is objective historicism, the treatment of history as a quasi-scientific intellectual pursuit, that is the deviant, detrimental offshoot from true historical perception," James Garratt, Palestrina and the German Romantic Imagination (New York: Cambridge University Press, 2002), p. 13.

15. See G. W. F. Hegel, The Philosophy of History. Trans. J. Sibree \& C. Hegel. (New York: Dover, 2004).

16. "If we place ourselves at the end of this tremendous process, where the tree at last brings forth the fruit, where society and the morality of custom at last reveal what they have simply been the means to: then we discover that the ripest fruit is the sovereign individual, like only to himself, liberated again from the morality of custom, autonomous and supramoral (for "autonomous" and "moral" are mutually exclusive), in short, the man who has his own independent, protracted will and the right to make promises - and in him a proud consciousness, quivering in every muscle, of what has at length been achieved and become flesh in him, a consciousness of his own power and freedom, a sensation of mankind come to completion", Nietzsche, On the Genealogy of Morality, (Indianapolis: Hackett Publishing, 1998), p. 35.

17. "As soon as we know that the blissful golden age of fantasy has never existed and never will, we are freed from the foolish tendency to over-praise some bygone age, from foolish despair of the present and from foolish hopes from the future, and can acknowledge that one of the noblest of all occupations is the study of times past, of the story of human life and human suffering as a whole," Burckhardt, Greeks, p. 364. "The Greeks, the most humane men of ancient times, have a trait of cruelty, a tigerish lust to annihilate," Nietzsche, "Homer's Contest," The Portable Nietzsche, (New York: Viking, 1976), p. 32.

18. See Suzanne Marchand's, Down from Olmypus: Archaeology and Philhellenism in Germany, 1750-1970. (Princeton: Princeton University Press, 2003).

19. Marchand, p. 6.

20. "From the time of Winckelmann and Lessing, and of Voss's translation of Homer, a feeling has grown up of the existence of a 'sacred marriage' (hieros gamos) between the spirit of Greece and spirit of Germany, a special relationship and sympathy shared by no other Western people in modern times." - Burckhardt, Jacob. 
The Greeks and Greek Civilization. Trans. Sheila Stern. (New York: St. Martin's Press, 1998), p. 11.

21. See "The Fundamental question of metaphysics" from Heidegger's Introduction to Metaphysics (New Haven: Yale University Press, 2000).

22. Nietzsche, Will to Power. Trans. Anthony Ludovici.(New York: Vintage, 1968), p. 419.

23. See Dennis Schmidt, On Germans and Other Greeks: Tragedy and Ethical Life (Bloomington: Indiana University Press, 2001).

24. "Fundamental assumptions that have saturated Western cultures for centuries, assumptions found powerfully present in metaphysics, Christianity, sciences, technology, as well as the influence of these upon the real formations of cultural and political life, now reveal themselves as presumptions which we can no longer share. So it seems that today the only shared assumption is that the present age is a time in need of radical transformation." Schmidt, p. 5.

25. Schmidt, p. 5.

26. See M.S. Silk and J.P. Stern, Nietzsche on Tragedy (Cambridge: Cambridge University Press, 1983), chapter 1.

27. Friedrich Schiller, The Poetical Works of Friedrich Schiller, "The Gods of Greece," (Charleston: Bibliobazaar, 2009). "Germany itself stands so high in every department, that we can scarcely survey all it has done, and now we must be Greeks," Goethe, Conversations of Goethe (Cambridge: Da Capo Press, 1998).

28. See Silk and Stern, p.7.

29. Richard Armstrong, A Compulsion for Antiquity: Freud and the Ancient World (Ithaca: Cornell University Press, 2006).

30. The quote "man is the dream of a shadow" is attributed to Pindar.

31. See also Lacan's related "mirror stage."

32. Heidegger, Introduction to Metaphysics, p. 30.

33. In a late letter, Nietzsche recalls that Burckhardt referred to Schopenhauer as "our philosopher" in conversation. Friedrich Nietzsche, Selected Letters of Friedrich Nietzsche, p. 212.

34. See J.W. Burrow, The Crisis of Reason: European Thought 1848-1914 (New 
Haven: Yale University, 2000).

35. Here I mean to reference, among other theories, Boltzmann's statistical

thermodynamics, Cantor's explorations of multiform infinities, Einstein's relativity and Freud's exploration of the unconscious; see William Everdell, The First Moderns (Chicago: University of Chicago Press, 1997).

36. See in particular the section "On Rousseau and his Utopia" in Burckhardt's On History and Historians.

37. See Jürgen Habermas, The Philosophical Discourse of Modernity (Cambridge: MIT Press, 1990).

38. "It is self-evidently the special duty of the educated to perfect and complete, as well as they can, the picture of the continuity of the world and making from the beginning. This marks off conscious beings from the unconscious barbarian. The vision of both past and future is what distinguishes human beings from the animals' and for us the past may have its reproaches, and the future its anxieties, of which animals know nothing," Burckhardt, Greeks, p. 12.

39. Burckhardt, On History and Historians, p. 231. Compare: "Will and wave. How greedily this wave approaches, as if there were some objective to be reached!" Friedrich Nietzsche, The Gay Science. (New York: Vintage, 1974), \#310.

40. Burckhardt, On History and Historians, p. 229.

41. In chapter 1 of Basel, Gossman has noted that Basel was sometimes known as "pious Basel" due to strong the city's religious heritage. It is worth noting that Burckhardt and Nietzsche had intended to pursue religious studies at the inception of their formal schooling.

42. Burckhardt, Reflections on History. Trans. M.D. Hottinger. (Indianapolis: Liberty Fund, 1979), p.42.

43. See Kant's essay "What is Enlightenment?" in Foundations of the Metaphysics of Morals and What is Enlightenment? (New York: Macmillan, 1990).

44. Gossman, Basel, p.452.

45. When asked by a scholar for "proof, just a single piece of ancient evidence, that in reality the strange images of the 'stage' were mirrored back from the magical dream of the ecstatic Dionysian chorus" (as claimed in Birth of Tragedy), Nietzsche soberly replied, as he only could:"Just how, then, should the evidence approximately be read?...Now the honorable reader demands that the whole problem should be 
disposed of with a single attestation, probably out of the mouth of Apollo himself." James Porter, The Invention of Dionysus, (Stanford: Stanford University Press, 2000), p. 41. From Nietzsche's letters we know that he attended Burckhardt's lectures on history.

46. "We can never cut ourselves off from antiquity unless we intend to revert to barbarism. The barbarian and the creature of exclusively modern civilization both live without history," Burckhardt, Greeks, p. 364.

47. One of Nietzsche's best known aphorisms, I repeat here in full: "The greatest stress. How, if some day or night a demon were to sneak after you into your loneliest loneliness and say to you, 'This life as you now live it and have lived it, you will have to live once more and innumerable times more; and there will be nothing new in it but every pain and every joy and every thought and sigh and everything immeasurably small or great in your life must return to you - all in the same succession and sequence - even this spider and this moon light between the trees, and even this moment and I myself. The eternal hourglass of existence is turned over and over, and you with it, a dust grain of dust.' Would you not throw yourself down and gnash your teeth and curse the demon who spoke thus? Or did you once experience a tremendous moment when you would have answered him, 'You are a god, and never have I heard anything more godly.' If this thought were to gain possession of you, it would change you, as you are, or perhaps crush you. The question in each and every thing, 'Do you want this once more and innumerable times more?' would weight upon your actions as the greatest stress. Or how well disposed would you have to become to yourself and to life to crave nothing more fervently than this ultimate eternal confirmation and seal?" - Nietzsche, The Gay Science, (New York: Vintage 1974), \#341.

48. In Burckhardt's final summation of his life (Lebensbericht), written in old age, he noted that the "death of his mother when he was twelve years old had left him with a sense of the 'great caducity and uncertainty of all earthly things' and probably had instilled in him for the rest of his life a most serene temperament. This early impression pervades all his works and ... is the core of his entire historical vocation." Joseph Mali, Mythistory: The Making of a Modern Historiography (Chicago: University of Chicago Press, 2003), p. 91. Note also that Nietzsche lost his father at a young age and doubtless this experience shaped his formative ideas about the fragility of life.

49. See Kaufmann, Nietzsche.

50. See in particular Burckhardt's On History and Historians and his later letters.

51. In a letter from 1842 Burckhardt writes: "I have never yet thought philosophically, and never had any thought at all that was not connected with something external. I can do nothing unless I start out from contemplation." Burckhardt, Letters, p. 45. 
52. Schopenhauer, The World As Will and Representation, 1:309.

53. This quote is equally attributable to a number of ancient sources, including Herodotus, Solon and Sophocles. According to Burckhardt, "Homer was supposed to have replied to the question what was best for mankind: 'above all, not to be born, or else to pass through Hades' gate as soon as may be,'” Burckhardt, Greeks, p. 105.

54. Schopenhauer, The World As Will and Representation, 1:309.

55. In answer to the claim cynicism was an "ascetic" philosophy, Burckhardt replied: "Cynicism...was not at all ascetic in the sense of trying to detach men from the world; its aim was only to help the individual, still living in the midst of the world, to reject its mastery over his will.” Burckhardt, Greeks, p. 101.

56. Burckhardt, Reflections on History, p. 316.

\section{See Nietzsche, Homer's Contest.}

58. "As for progress, there are two things to be said. First, it is obviously an error to think that intellectual progress must necessarily be preceded by the material enrichment and refinement of life, on the premises that barbarism can only disappear when poverty is overcome. In certain favored races, even when the culture is materially primitive, and in the absence of that 'comfort' ... [which is prized] so highly...we see the most perfect and abundant beauty in all that relates to the inner life of the people. What, for example, can surpass the story of Nausicaa in spiritual beauty and delicacy? Similarly, material wealth and refinement of living conditions are no guarantee against barbarism. The social classes that have benefited from this kind of progress are often, under a veneer of luxury, crude and vulgar in the extreme and those whom it has left untouched even more so. Besides, progress brings with it the exploitation of and exhaustion of the earth's surface, as well as the increase and consequent proletarianization of the urban population, in short, everything that leads inevitably to decline, to the condition in which the world casts about for 'refreshment' from the as yet untapped powers of Nature, that is, for a new 'primitiveness' - or barbarism." - Burckhardt, Greeks, pp. 135-136.

59. Burckhardt, Reflections on History, p. 319.

60. Burckhardt, Reflections on History, p. 320.

61. Burckhardt, Reflections on History, p. 319.

62. See Michel Foucault, Order of Things: An Archaeology of the Human Sciences (New York: Routledge, 2001). In the introduction to Burckhardt's Greeks, 
Oswyn Murray has furthermore offered the opinion that "[In the nineteenth century] History replaced philosophy as the fundamental science of human nature and the explanation of all human society."

63. In his Ecce Homo, Nietzsche identified Birth of Tragedy as a "defiance of all the known prejudices of our democratic age, that the great optimist-rationalistutilitarian victory, together with democracy, its political contemporary, was at bottom nothing other than a symptom of declining strength, approaching senility, somatic exhaustion..."

64. In On the Genealogy of Morality, Nietzsche argues that the human being of ressentiment, "is neither sincere, nor naïve, nor honest or frank with himself"; for the reason that he conceives of happiness as being activated from without - it is "alienated" by nature insofar as it is defined as an antithesis to their separation from material satisfaction which nature, which the "noble-born" perpetuate; happiness in modernity is extrinsic to "life."

65. Burckhardt, Reflections on History, p. 215.

66. See Felix Gilbert, History: Politics or Culture? Reflections on Ranke and Burckhardt (Princeton: Princeton University Press, 1990).

67. Gilbert, p. 89.

\section{Notes: Chapter III}

1. I mean to implicate here in particular the Rousseauian moral philosophy implicit in Immanuel Kant, Critique of Practical Reason. Trans. Mary Gregor. (Cambridge: Cambridge University Press, 1997).

2. See Gossman "Boundaries."

3. Gossman, "Boundaries," p. 49.

4. "One great advantage of studying cultural history is the certainty of its more important facts, compared with those of history in the ordinary sense of narrated events: these are frequently uncertain, controversial, coloured, or, given the Greek talent for lying, entirely the invention of imagination or self-interest. Cultural history by contrast possesses a primary degree of certainty, as it consists for the most part of material conveyed in an unintentional, disinterred or even involuntary way by sources and monuments; they betray their secrets unconsciously and even, paradoxically, through fictitious elaborations, quite apart from the material details they may set out to record and glorify, and are thus doubly instructive for the cultural historian." Burckhardt, Greeks, p. 5 . 
5. Among other theorists, Žižek cites Kant as a paramount philosopher of "finitude." See Slavoj Žižek, The Parallex View (Cambridge: MIT Press, 2009).

6. "Out of the crooked timber of humanity no straight thing was ever made," Immanuel Kant, "Idea for a Universal History from a Cosmopolitan Point of View," in Perpetual Peace and Other Writings, (New Haven: Yale University Press, 2006).

7. See Jacques Derrida, "Plato's Pharmacy, Dissemination , (Chicago: University of Chicago Press, 1983).

8. Derrida, "Plato," p. 2.

9. See Porter, Dionysus.

10. Kritische Studienausgabe (Nietzsche) 7:7[201]; 216.

11. Schopenhauer, World, 1:275.

12. In his article "Nietzsche: Utility, Aesthetics, History," Robert Doran describes Nietzsche's endeavor to establish a "new objectivity."

13. Nietzsche, On the Advantage and Disadvantage of History for Life. Trans. Peter Preuss. (Indianapolis: Hackett, 1980), p. 35.

14. Doran, "Nietzsche: Utility, Aesthetics, History," Comparative Literature Studies 37(2000): p. 326.

15. What is intrinsic to nature, Nietzsche hypothesizes, is "an indifferent point" that subtends and even mocks every aesthetic judgment that is projected onto it: "There is no natural beauty, but there is indeed the distressing and ugly, and an indifferent point," See Porter, "Primordial Fairy Tales," in Invention of Dionysus. (Stanford: Stanford University Press, 2000) p. 126.

16. "If contradiction is the true Being...then to understand the world in its depths means understanding the contradiction." Nietzsche, Kritische Studienausgabe, $7: 19[91]$.

17. Nietzsche, Großoktavausgabe (XII, i, 89).

18. Nietzsche, Großoktavausgabe (XII, i, 89).

19. Nietzsche, On History, section 1.

20. See Doran, "Nietzsche: Utility, Aesthetics, History." 
21. See Plato, Complete Works: Republic, Book III (Indianapolis: Hackett, 1997).

22. See Kant, Critique of Judgment (Cambridge: Cambridge University Press, 2001), \#1.

23. Kai Hammermeister, The German Aesthetic Tradition (Cambridge:

Cambridge University Press, 2002), p. 29.

24. See the discussion of Kant in Hammermeister's The German Aesthetic

\section{Tradition.}

25. Hammermeister, p. 29

26. See Terry Eagleton, Ideology of the Aesthetic (Oxford: Blackwell, 1991).

27. See Allan Megill, Prophets of Extremity: Nietzsche, Heidegger, Foucault, Derrida (Berkeley: University of California Press, 1987).

28. "Without myth every culture loses the healthy natural power of its creativity: only a horizon defined by myths completes and unifies a whole cultural movement...The images of myth have to be the unnoticed omnipresent demonic guardians, under whose care the young soul grows to maturity and whose signs help the man to interpret his life and struggles. Even the state knows no more powerful unwritten laws than the mythical foundation that guarantees its connection with religion and its growth from mythical notions," Nietzsche, Birth of Tragedy, \#23.

29. Megill, p. 52.

30. See Albert Salomon, "Jacob Burckhardt: Transcending History." Philosophy and

Phenomenological Research 6(1945): 225-269.

31. Salomon, p. 226.

32. Salomon, p. 226.

33. Salomon, p. 249.

34. "In humanity, the primordial unity looks back upon itself by means of appearance: appearance reveals the essence. That means: the primordial unity views 
humanity, rather, the appearance viewing humanity, humanity which sees through the appearance," Nietzsche, Kritische Gesamtausgabe (Werke), 3:213.

35. Hammermeister, p. 33.

36. Kant, Critique of Judgment, \#28.

37. Hammermeister, p. 33.

38. Heidegger, Metaphysics, p. 88.

39. Kant, Critique of Judgment, \#28.

40. Burckhardt, Letters, p. 204.

\section{Notes: Chapter IV}

1. Foucault, "Nietzsche, Genealogy, History," The Foucault Reader. (New York: Vintage, 1984). "The true world - we have abolished. What world has remained? The apparent one perhaps? But no! With the true world we have also abolished the apparent one," Nietzsche, Twilight of the Idols (Indianapolis: Hackett Publishing Company, 1997), "How the True World Finally Became a Fable."

2. Nietzsche, Thus Spoke Zarathustra, Second Part, \#22.

3. Burckhardt, Greeks, p. 3.

4. In a letter from June, 1842 Burckhardt stated: "You philosophers go further, your system penetrates into the depths of the secrets of the world, and to you history 
is a source of knowledge, a science, because you see, or think you see, the primum agens where I only see mystery and poetry," Letters, p. 45.

5. Burckhardt, Reflections on History, chapter 2.

6. Aleatoricism is the creation of art by chance, through overtly random processes and was made popular in particular through Surrealism and Dadaism in the beginning part of the twentieth century.

7. Burckhardt, Reflections on History, p. 98.

8. "The essence of history is change" - Burckhardt, from the introduction to Reflections on History."What, then, is truth? A mobile army of metaphors, metonyms, and anthropomorphisms -- in short, a sum of human relations which have been enhanced, transposed, and embellished poetically and rhetorically, and which after long use seem firm, canonical, and obligatory to a people: truths are illusions about which one has forgotten that this is what they are; metaphors which are worn out and without sensuous power; coins which have lost their pictures and now matter only as metal, no longer as coins," Nietzsche, "Truth and Lie in an Extra-Moral Sense," The Portable Nietzsche, p. 45.

9. Salomon, p. 234.

10. Salomon, p. 232.

11. The reference here, with the term, "involuntary recollection," is to Proust.

12. "If we have our own why of life, we shall get along with almost any how," Nietzsche, Twilight of the Idols, p. 12.

13. See Mali's Mythistory, chapter 3.

14. This quote is attributable to Renan's essay, "What is a Nation?"

15. See Mali, chapter 3.

16. Mail, p. 236.

17. Herodotus, The Histories (New York: Everyman's Library, 1997), Book I.

18. Nietzsche's and Heidegger's keen interest in the pre-Socratics among other less "traditional" antique sources was, possibly, inspired by this Burckhardtian precedent.

19. Burckhardt, Greeks, p. 10. 
20. Burckhardt, Greeks, p. 5.

21. Burckhardt, Greeks, p. 240.

22. Burckhardt, Greeks, p. 238.

23. Burckhardt, Greeks: Part III.

24."The goal of humanity cannot lie at the end but only in its highest specimens," Nietzsche, History, p. 9.

25. Nietzsche, Thus Spoke Zarathustra, Prologue.

26. Sigurdson, p. 217.

27."[For the Greeks,] the agon occupied the whole of existence," Burckhardt, Greeks, p. 185.

28. Sigurdson, p. 121.

29. Burckhardt, Greeks: "The Agonal Age."

30. Burckhardt, Greeks: "The Agonal Age."

31. Burckhardt, Greeks, p. 71.

32. "It was during those long years of work on Greichische Kulturgeschichte...that Burckhardt immersed himself in Pausanias. [The latter's] Description of Greece was the only book that Burckhardt carried with him from Basel on his vacation in Baden im Aargau in the summer of 1889. In this book Burckhardt found much that resembled his own world and works," Mali, p. 128.

33. Mali, p. 128.

34. Mali quoting Pausanias: "I know that fortune alters everything, strong and weak, things at their beginning and things at their ending, and drives everything with a strong necessity and according to her whim. Mycenae [is now] deserted and demolished...This is how temporary and completely insecure human things are," Mali, p. 130.

35. See Nietzsche, The Gay Science, \#34.

36. Burckhardt, Greeks, p. 268. 
37. Burckhardt, Greeks, p. 268.

38. Burckhardt, Greeks, p. 268.

39. The German mathematician Bernhard Reimann had only given his epochal lecture on non-Euclidean geometry some ten years before Burckhardt's Greeks were issued.

40. Betrand Russell, History of Western Philosophy (Clearwater: Touchstone, 1967), p. 78.

41. Nietzsche wrote in his notebooks from 1887: "I am not bigoted enough for a system -- and not even for my system," (XIV, 313).

42. "Like the dialogical Plato...the aphoristic Nietzsche is a great anti-systematist to whom other philosophers perversely persist in ascribing a system in their own doctrinal or deductivist sense of 'system.' Nietzsche is not dialectical in the pursuit of system, like Hegel or Schopenhauer. He is, rather, dialectical in the heuristic or Socratic sense of a discursive searcher...A basic reason for which Nietzsche rejected system-building, is that he wished always to remain free to question his own premises." V. Tejera, Nietzsche and Greek Thought (New York: Springer, 1987), p. 95.

43. See Foucault, The Foucault Reader, "Nietzsche, Genealogy, History."

44. Nietzsche, Twilight of the Idols, \#77.

45. Burckhardt, Greeks, p. 265.

46. Foucault, The Foucault Reader, "Truth and Power."

47. Burckhardt and Nietzsche were perhaps the first moderns to comprehend the totality of Machiavellianism in a way that Enlightenment and Romantic thinkers did not grasp.

48. Foucault, The Foucault Reader, "Nietzsche, Genealogy, History."

49. Foucault, The Foucault Reader, "Truth and Power."

\section{Notes: Chapter V}

1. Sigurdson, Social and Political, p. 213.

2. "Every human being only has dignity in so far as he is a tool of the genius," Nietzsche, Morality, \#176. 
3. The evolutionism vs. catastrophism controversy in science raged throughout the nineteenth century.

4. See Gossman, Basel, p. 268.

5. See Sigurdson, chapter 6.

6. Sigurdson, Social and Political, p. 201.

7. Sigurdson, Social and Political, p. 201.

8. It is of course a subject of great controversy as to whether such attempts to appropriate Nietzschean philosophy -- and certainly Nazism is the most infamous of many examples -- were carried out in a way congruent with Nietzsche's own intentions.

9. See Nietzsche, Twilight, "'Reason' in philosophy"; "'All truth is simple. Is that not doubly a lie?" Nietzsche, Twilight, \#4.

10. See Max Horkheimer and Theodor Adorno, Dialectic of Enlightenment (New York: Continuum, 1994), Section 1.

11. Nietzsche, Gay Science, \#356.

12. Burckhardt, Reflections on History, p. 67.

13. Nietzsche, History, p. 45.

14. "The time of highest flowering was also that of the most horrific executions," Burckhardt, Greeks: "The Polis."

15. Burckhardt, Greeks, p. 46.

16. Burckhardt, Greeks, p.. 57.

17. "From time immemorial, worldly power had admitted of few restrictions on its [the polis] actions whenever its interests were involved," Burckhardt, Greeks: "The Polis."

18. Gossman, Basel, p. 333.

19. Burckhardt, Greeks: "The Fifth Century."

20. Gossman, Basel, p. 338. 
21. Burckhardt, Greeks, p. 86.

22. Burckhardt, Greeks, p. 102.

23. Heidegger, Metaphysics, p. 41.

24. Gossman, Basel in the Age of Burckhardt, p. 333.

25. Burckhardt, Greeks, p. 95.

26. Burckhardt, Greeks, p. 88.

27. Burckhardt recalls, in a letter, that Ranke began his lectures with the pronouncement: "Gentlemen, nations are God's thoughts!", Letters, p. 20.

28. Schmidt, Germans, chapter 1.

29. Schmidt, Germans, chapter 1. 


\section{Works Cited:}

Armstrong, Richard. A Compulsion for Antiquity: Freud and the Ancient World. Ithaca:

Cornell University Press, 2006.

Isaiah Berlin, "The Counter-Enlightenment." The Proper Study of Mankind: An Anthology of Essays. New York: Farrar, Straus and Giroux, 2000.

Burckhardt, Jacob. The Civilization of the Renaissance in Italy. Trans. S. G. C. Middlemore. New York: Penguin, 1990.

---. The Greeks and Greek Civilization. Trans. Sheila Stern. New York:

St. Martin's Press, 1998.

---. On History and Historians. Trans. Harry Zohn. New York: Harper Torchbooks, 1958.

---. The Letters of Jacob Burckhardt. Trans. Alexander Dru. Indianapolis:

Liberty Fund, 2001.

---. Reflections on History. Trans. M.D. Hottinger. Indianapolis: Liberty Fund, 1979.

Burrow, J.W. The Crisis of Reason: European Thought 1848-1914. New Haven: Yale University Press, 2000.

Derrida, Dissemination: "Plato's Pharmacy." Chicago: University of Chicago Press, 1983.

Doran, Robert. "Nietzsche: Utility, Aesthetics, History." Comparative Literature Studies. 37 (2000): 321-343.

Eagleton, Terry. The Ideology of the Aesthetic. Oxford: Blackwell, 1991.

Everdell, William. The First Moderns. Chicago: University of Chicago Press, 1997.

Foucault, Michel. The Order of Things: An Archaeology of the Human Sciences. New York: Routledge, 2001.

---. The Foucault Reader. edited by Paul Rabinow. New York: Pantheon Books, 1984.

Garratt, James. Palestrina and the German Romantic Imagination. New York: Cambridge University Press, 2002. 
Gilbert, Felix. History: Politics or Culture? Reflections on Ranke and Burckhardt. Princeton: Princeton University Press, 1990.

Goethe, Conversations of Goethe. Cambridge: Da Capo Press, 1998.

Gossman, Lionel. Basel in the Age of Burckhardt: A Study in Unseasonable Ideas. Chicago: University of Chicago Press, 2002.

---. "The Boundaries of the City: A Nineteenth Century Essay on 'The Limits of Historical Knowledge." History and Theory 25 (1986): 33-51.

Habermas, Jürgen. The Philosophical Discourse of Modernity. Cambridge: MIT Press, 1990.

Hammermeister, Kai. The German Aesthetic Tradition. Cambridge: Cambridge University Press, 2002.

Hegel, G. W. F. Trans. J. Sibree \& C. Hegel. The Philosophy of History. New York: Dover, 2004.

Heidegger, Martin. Introduction to Metaphysics. Trans. Gregory Fried and Richard Polt. New Haven: Yale University Press, 2000.

Herodotus. The Histories. Trans. David Greene. Chicago: University of Chicago Press, 1987.

Guyer, Paul. Kant. London: Routledge, 2006.

Hill, R. Kevin. Nietzsche's Critiques: The Kantian Foundations of His Thought. Oxford: Oxford University Press, 2005.

Hinde, John. Jacob Burckhardt and the Crisis of Modernity. Montreal: McGillQueen's University Press, 2000.

Horkheimer, Max and Theodor Adorno. Dialectic of Enlightenment. Trans. John Cumming. New York: Continuum, 1994.

Kant, Immanuel. Critique of Judgment. Cambridge: Cambridge University Press, 2001.

---. Critique of Practical Reason. Cambridge: Cambridge University Press, 1997.

---. Critique of Pure Reason. Trans. Werner S. Pluhar. Indianapolis:

Hackett, 1996. 
---. Foundations of the Metaphysics of Morals and What is Enlightenment? New York:

Macmillan, 1990.

---. Observations on the Feeling of the Beautiful and Sublime. Trans. John T.

Goldthwait.

Berkeley: University California Press, 1960.

---. Perpetual Peace and Other Writings. Trans. David L. Colclasure. New Haven:

Yale University Press, 2006.

Kaufmann, Walter. Nietzsche: Philosopher, Psychologist, Antichrist. Fourth ed. Princeton: Princeton University Press, 1974.

Mali, Joseph. Mythistory: The Making of a Modern Historiography. Chicago:

University of Chicago Press, 2003.

Marchand, Suzanne. Down from Olympus: Archaeology and Philhellenism in Germany 1750-1970. Princeton: Princeton University Press, 2003.

Megill, Allan. Prophets of Extremity: Nietzsche, Heidegger, Foucault, Derrida. Berkeley: University of California Press, 1985.

Meinecke, Friedrich. Letters and Documents: 1910-1977. Boston: Brill Academic Publishers, 2010.

Murray, Oswyn. “Centaur or Cicerone?” The Classical Review 15 (1965): 209-212.

Nietzsche, Friedrich. The Birth of Tragedy/The Case of Wagner. Trans. Walter Kaufmann. New York: Vintage, 1967.

---. Beyond Good and Evil New York: Vintage, 1966.

---. Ecce Homo. Trans. R.J. Hollingdale. New York: Penguin, 1992.

---. The Gay Science. Trans. Walter Kaufmann. New York: Vintage, 1974.

---. On the Advantage and Disadvantage of History for Life. Trans. Peter Preuss. Indianapolis: Hackett, 1980.

---. On the Genealogy of Morality. Trans. Maudemarie Clark and Alan Swensen. Indianapolis: Hackett, 1998. 
---. “On Homer's Contest.” Trans. Walter Kaufmann. New York: Penguin, 1976.

---. “On Truth and Lie in an Extra-Moral Sense.” trans. Walter Kaufmann. I Harmondsworth: Penguin, 1976.

---. The Portable Nietzsche. Edited and translated by Walter Kaufmann. New York: Penguin, 1976.

---. Selected Letters of Friedrich Nietzsche. Trans. Christopher Middleton. Indianapolis: Hackett, 1996.

---. Thus Spake Zarathustra. Trans. Thomas Common. New York: Prometheus Books, 1993.

---. Twilight of the Idols. Trans. Duncan Large. Oxford: Oxford University, 1998.

---.The Will to Power. Trans. Kaufmann and Hollingdale. New York: Vintage, 1968.

Plato. Complete Works. Editor John M. Cooper. Indianapolis: Hackett, 1997.

Porter, James. The Invention of Dionysus. Stanford: Stanford University Press, 2000.

Rusen, Jorn. "Jacob Burckhardt: Political Standpoint and Historical Insight on the Border of Post-Modernism." History and Theory 24 (1985): 235-246.

Russell, Bertrand. The History of Western Philosophy. New York: Simon \& Schuster, 1972.

Salomon, Albert. "Jacob Burckhardt: Transcending History." Philosophy and Phenomenological Research 6(1945): 225-269.

Schiller, Friedrich. “The Gods of Greece,” The Poetical Works of Friedrich Schiller. Charleston: Bibliobazaar, 2009.

Schmidt, Dennis. On Germans and Other Greeks: Tragedy and Ethical Life. Bloomington: Indiana University Press, 2001.

Schopenhauer, Arthur. The World as Will and Representation. Trans. E.F.J. 2 vols. Payne. New York: Dover, 1969.

Sigurdson, Richard. Jacob Burckhardt's Social and Political Thought. Toronto: University of Toronto Press, 2004. 
---. "Jacob Burckhardt: The Cultural Historian as Political Thinker." The Review of Politics 52 (1990): 417-440.

Silk, M.S. and J.P. Stern. Nietzsche on Tragedy. Cambridge: Cambridge University Press, 1983.

Tejera, V. Nietzsche and Greek Thought. New York: Springer, 1987.

Weber, Max. From Max Weber: Essays in Sociology. New York: Oxford Press, 1958.

Young, Julian. Schopenhauer. New York: Routledge, 2005.

Žižek, Slavoj. The Parallex View. Cambridge, The MIT Press, 2009. 